\title{
Pollen-based reconstruction of Holocene vegetation and climate in southern Italy: the case of Lago Trifoglietti
}

\author{
S. Joannin ${ }^{1,2,3}$, E. Brugiapaglia ${ }^{4}$, J.-L. de Beaulieu ${ }^{5}$, L. Bernardo ${ }^{6}$, M. Magny $^{2}$, O. Peyron ${ }^{2}$, S. Goring ${ }^{7}$, and \\ B. Vannière ${ }^{2}$ \\ ${ }^{1}$ CNRS - USR3124 MSHE Ledoux, Besançon, France \\ ${ }^{2}$ CNRS - UMR6249 Laboratoire Chrono-Environnement, Université de Franche-Comté, Besançon, France \\ ${ }^{3}$ CNRS - UMR5276 LGL TPE, Université Lyon 1, Villeurbanne, France \\ ${ }^{4}$ Dipartimento di Scienze Animali, Vegetali e dell'Ambiente, Università degli Studi del Molise, Campobasso, Italy \\ ${ }^{5}$ CNRS - UMR7263 IMBE, Université d'Aix-Marseille, Aix en Provence, France \\ ${ }^{6}$ Orto botanico, Università della Calabria, Cosenza, Italy \\ ${ }^{7}$ Department of Geography, University of Wisconsin-Madison, Wisconsin, USA
}

Correspondence to: S. Joannin (sebastien.joannin@univ-lyon1.fr), E. Brugiapaglia (e.brugiapaglia@unimol.it), J.-L. de Beaulieu (jacques-louis.debeaulieu@imbe.fr), L. Bernardo (1.bernardo@unical.it),

M. Magny (michel.magny@univ-fcomte.fr), O. Peyron (odile.peyron@univ-fcomte.fr), S. Goring (goring@wisc.edu), and B. Vannière (boris.vanniere@univ-fcomte.fr)

Received: 1 June 2012 - Published in Clim. Past Discuss.: 15 June 2012

Revised: 10 October 2012 - Accepted: 12 November 2012 - Published: 7 December 2012

\begin{abstract}
A high-resolution pollen record from Lago Trifoglietti in Calabria (southern Italy) provides new insights into the paleoenvironmental and palaeoclimatic changes which characterise the Holocene period in the southern Italy. The chronology is based on 11 AMS radiocarbon dates from terrestrial organic material. The Holocene history of the vegetation cover shows the persistence of an important and relatively stable Fagus forest present over that entire period, offering a rare example of a beech woodstand able to withstand climate changes for more than 11000 yr. Probably in relation with early Holocene dry climate conditions which affected southern Italy, the Trifoglietti pollen record supports a southward delay in thermophyllous forest expansion dated to ca. $13500 \mathrm{cal} \mathrm{BP}$ at Monticchio, ca. $11000 \mathrm{cal} \mathrm{BP}$ at Trifoglietti, and finally ca. 9800 cal BP in Sicily. Regarding the human impact history, the Trifoglietti pollen record shows only poor imprints of agricultural activities and anthopogenic indicators, apart from those indicating pastoralism activities beneath forest cover. The selective exploitation of Abies appears to have been the strongest human impact on the Trifoglietti surroundings. On the basis of (1) a specific ratio between hygrophilous and terrestrial taxa, and (2) the Modern Analogue Technique, the pollen data collected at Lago Trifoglietti led to the establishment of two palaeoclimatic
\end{abstract}

records tracing changes in (1) lake depth and (2) annual precipitation. On a millennial scale, these records give evidence of increasing moisture from ca. 11000 to ca. $9400 \mathrm{cal} \mathrm{BP}$ and maximum humidity from ca. 9400 to ca. $6200 \mathrm{cal} \mathrm{BP}$, prior to a general trend towards the drier climate conditions that have prevailed up to the present. In addition, several successive centennial-scale oscillations appear to have punctuated the entire Holocene. The identification of a cold dry event around $11300 \mathrm{cal} \mathrm{BP}$, responsible for a marked decline in timberline altitude and possibly equivalent to the PBO, remains to be confirmed by further investigations verifying both chronology and magnitude. Two cold and possibly drier Boreal oscillations developed at ca. 9800 and $9200 \mathrm{cal} \mathrm{BP}$. At Trifoglietti, the $8.2 \mathrm{kyr}$ event corresponds to the onset of cooler and drier climatic conditions which persisted until ca. 7500 cal BP. Finally, the second half of the Holocene was characterised by dry phases at ca. 6100-5200, 4400-3500, and $2500-1800 \mathrm{cal} \mathrm{BP}$, alternating with more humid phases at ca. 5200-4400 and ca. 3500-2500 cal BP. Considered as a whole, these millennial-scale trends and centennial-scale climatic oscillations support contrasting patterns of palaeohydrological changes recognised between the north- and southcentral Mediterranean. 


\section{Introduction}

The major climate changes which developed from the end of the last Glacial to the Holocene are now relatively well established in Europe (e.g., Björck et al., 1996, 1998). On the continent, climate history is recorded through different indicators including vegetation changes driven by variations in the orbitally-induced insolation change and associated variations in climate parameters such as precipitation and growingseason temperature. Whereas the Holocene climate may appear as a relatively stable temperate period, it was, nethertheless, punctuated by numerous rapid cold events such as the Preboreal and Boreal oscillations (Björck et al., 1997, 2001; Fleitmann et al., 2007; Yu et al., 2010), the $8.2 \mathrm{kyr}$ event (Wiersma and Jongma, 2010) and the Neoglacial climate cooling at ca. 6000-5000 cal BP (Magny et al., 2006b; Miller et al., 2010).

These events are also recorded in the Mediterranean area, where they suggest a strong connection between higher and lower latitude regions (e.g., Asioli et al., 1999; Favaretto et al., 2008; Magny et al., 2006a, 2007b, 2009; Combourieu Nebout et al., 2009; Pross et al., 2009; Fletcher et al., 2010). However, on closer examination, paleoenvironmental records point to regional diversity in the effects of rapid climate change throughout the Mediterranean region (e.g., Roberts et al., 2011a; Magny et al., 2011a). This underscores the complexity of the Mediterranean climate, which may reflect contrasting influences from both higher latitudes (e.g., deglacial events, the North Atlantic Oscillation) and lower latitudes (e.g., the tropical monsoon) which, for instance, may have affected westerly activity and associated precipitation changes over the Italian Peninsula (Magny et al., 2002, 2007a; Zanchetta et al., 2007).

Moreover, particularly in the Mediterranean regions where human impact has been widespread at least since the $\mathrm{Ne}$ olithic (Guilaine, 2003), it is sometimes difficult to disentangle the climatic and anthropogenic forcing factors in palaeoenvironmental records (De Beaulieu et al., 2005; Roberts et al., 2011b). This complexity is reinforced by a possible climate determinism for human societies and by human-induced environmental changes (on a wider-thanlocal scale) which are expected to enhance regional climate impact (Jalut et al., 2009; Tinner et al., 2009). While the pollen proxy does not escape this ambiguity in paleoenvironmental reconstructions and interpretations (Sadori et al., 2010), it may be of great interest in providing direct and/or indirect evidence of anthropogenic activities (Mercuri et al., 2010).

Southern Italy is a place where climate and human influences are superimposed, with (1) orbitally induced long-term climate changes and possible short-term time-transgressive climate oscillations developing according to latitude (Di Rita and Magri, 2009), and (2) major cultural changes such as the Neolithic expansion in southeastern Italy between 9000 and $8000 \mathrm{cal} \mathrm{BP}$ and in south-western Italy between 8000 and

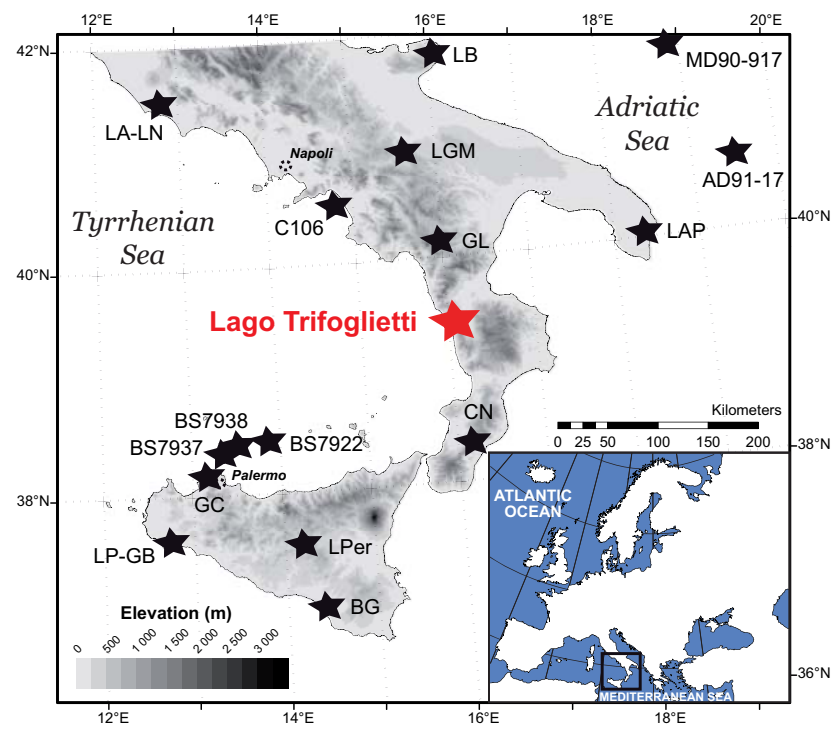

Fig. 1. Location of study site and other sites considered in the text: Lago Albano and Nemi (Ariztegui et al., 2000 and references therein), Lago Battaglia (Caroli and Caldara, 2007), Lago Alimini Piccolo (Di Rita and Magri, 2009), Lago Grande di Monticchio (Allen et al., 2002), C106 (Di Donato et al., 2008), Grotta di Latronico (Colonese et al., 2010), Canolo Nuovo (Schneider, 1985), Lago di Pergusa (Sadori and Narcisi, 2001), Biviere di Gela (Noti et al., 2009), Grotta di Carburangeli (Frisia et al., 2006), Gorgo Basso (Tinner et al., 2009), Lago Preola (Magny et al., 2011b; Calò et al., 2012), AD91-17 (Sangiorgi et al., 2003), BS7938 (Sbaffi et al., 2004), MD90-917 (Siani et al., 2012).

7500 cal BP (Guilaine, 2003; Berger and Guilaine, 2009). Thus, southern Italy is of great importance when discussing natural vs. anthropogenic forcing of vegetation changes. However, on the other hand, pollen-based Holocene vegetation records from southern Italy are still sparse and most of them are from low altitudes (Fig. 1). Only Lago Grande di Monticchio (656 m a.s.l.; Allen et al., 2002) and Lago di Pergusa in Sicily (667 m a.s.1.; Sadori et al., 2011) are located in the collinean belt, which are separated by $450 \mathrm{~km}$, provide a forest development asynchronism of ca. $4000 \mathrm{yr}$.

Palynological study of the Trifoglietti site in the meridional part of the Apennines help to fill the gaps between previous studies. It may give evidence of elements characterising long-term vegetation dynamics in a place close to glacial refugia, as well as of the possible influences of Holocene rapid climate changes and the Neolithic expansion on vegetation. Finally, it may provide additional data for a better understanding of regional climate variability and possible contrasting changes in seasonality between central and southern Italy (Magny et al., 2011a).

Having been informed about the nearly-infilled Lago Trifoglietti by a short pollen study published by Murgia et al. (1984), we have carried out new investigations there (1) to establish a new Holocene vegetation record in an 


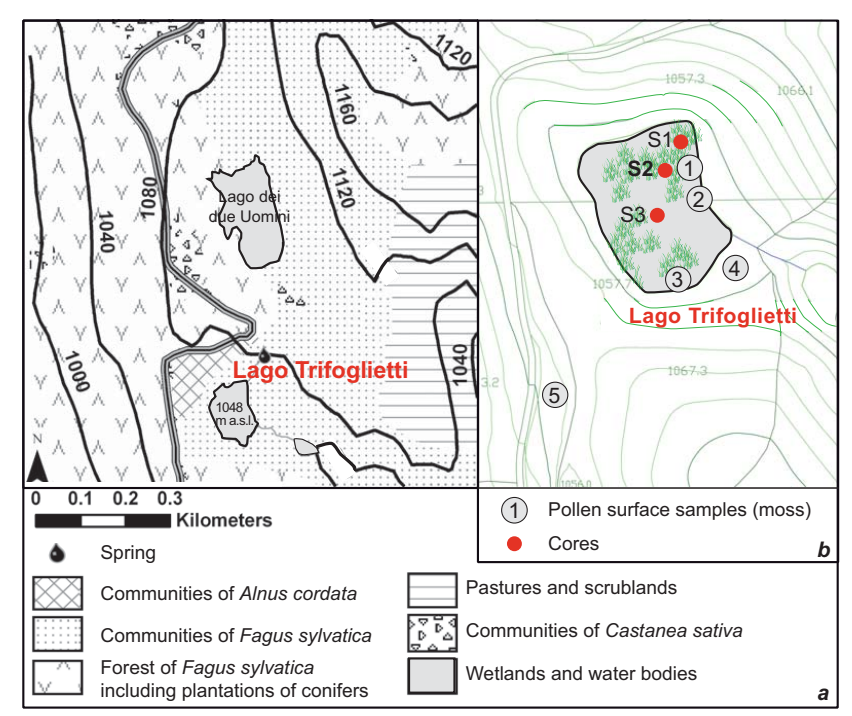

Fig. 2. (a) Actual vegetation map; (b) coring sites, surface samples and relevés localisation.

intermediate location between central Italy and Sicily, and (2) to reconstruct possible palaeohydrological (climatic) variations reflected by changes in vegetation.

\section{General description of the site}

\subsection{Location}

Lago Trifoglietti $\left(39^{\circ} 33^{\prime} \mathrm{N}, 16^{\circ} 01^{\prime} \mathrm{E}\right.$; $1048 \mathrm{~m}$ a.s.l.) is located in southern Italy (Fig. 1), near the town of Fagnano Castello in Cosenza province. Overlooked by Monte Caloria $(1183 \mathrm{~m})$, Lago Trifoglietti is part of a natural high-altitude lucustrine system inhabited by endemic amphibians (Sperone et al., 2007). Thus, protected within a Natura 2000 zone (SIC IT9310060 - Laghi di Fagnano), the lakes are located in the Catena Costiera Mountains which stretch parallel along the Tyrrhenian coast for $70 \mathrm{~km}$ with altitudes ranging from 1060 and $1541 \mathrm{~m}$ (Sperone et al., 2007). This part of the Catena Costiera belongs to the Liguride complex outcrop and is formed of metamorphic terrigenous deposits of a solidtextured green rock which is, consequently, only weakly eroded (Ogniben, 1973; Ogniben and Vezzani, 1976). The soils, classified as Dystric Cambisols by the World Reference Base (WRB) and as Dystrudept in Soil Taxonomy (ARSSA, 2003), are composed of high organic matter input to the mineral fraction units resulting in thin acid soils with a dark brown and lumpy texture.

The origin of the Catena Costiera lakes is not well established. Guerricchio (1985) suggests that they were created by large landslides and were filled by spring overflow. Initially, the lakes had an elongated shape, following the direction of depression created behind the landslide body, but subsequent

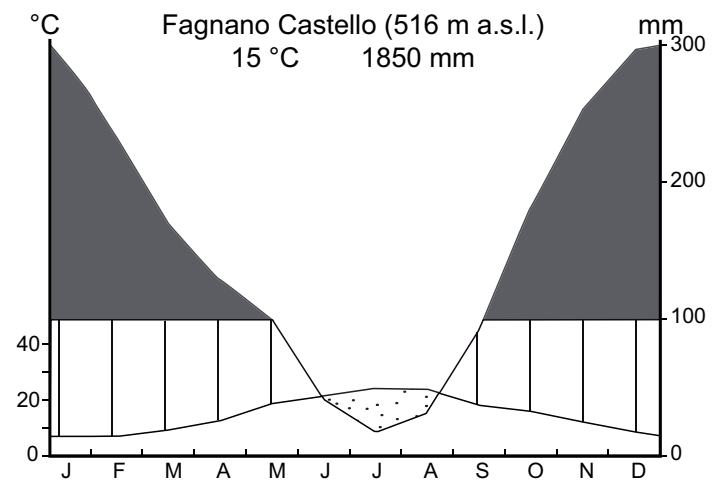

Fig. 3. Ombrothermic diagram of the meteorological station of Fagnano Castello, about $3 \mathrm{~km}$ away from Lago Trifoglietti. This station is on the eastern side of the mountain range, and the record ran for 42 yr (1921-1968; Ciancio, 1971).

infilling with material from mountain runoff progressively gave them a rounded shape.

At Trifoglietti nowadays, a spring flows into the lake from the north; an outflow runs southward (Fig. 2a-b). To combat summer drought, the Municipality of Fagnano Castello built a small earthen dam in 2000. With a surface area of 0.973 ha and a catchment area covering $0.370 \mathrm{~km}^{2}$, the lake reaches a depth of up to $1.50 \mathrm{~m}$.

\subsection{Climate and phytogeography}

\subsubsection{Climate}

Due to its geographical position and to its relatively high elevation a.s.l., the climate of the Trifoglietti region is greatly influenced by warm and humid air masses from the Tyrrhenian Sea. Despite the strictly Mediterranean latitude of the study area, annual rainfall can reach more than $1800 \mathrm{~mm} \mathrm{yr}^{-1}$ (Fig. 3), though a relatively short dry period develops in summer (Ciancio, 1971). According to the bioclimatic classification proposed by Rivas-Martinez (1993) and based on both corrected summer ombrothermic index $\left(I_{\mathrm{ovc}}\right)$ and the corrected thermic index $\left(I_{\mathrm{tc}}\right)$, the Trifoglietti area falls within the "lower mesotemperate bioclimate belt" of a temperate region and the ombrotype is "upper hyperhumid". Mean annual temperature is $15^{\circ} \mathrm{C}$, with $24^{\circ} \mathrm{C}$ for August and $7.5^{\circ} \mathrm{C}$ for January.

\subsubsection{Phytogeography}

The Catena Costiera vegetation is dominated by Fagus sylvatica, Quercus cerris and Castanea sativa. The lake is surrounded by a beech forest attributed to Anemono apenninaeFagetum with some Pinus nigra subsp. laricio. Scrub vegetation, with Erica arborea, Cistus salvifolius, Helichrysum italicum, Sarothamnus scoparius and Alnus cordata trees, develops in the more open Fagus forests. 


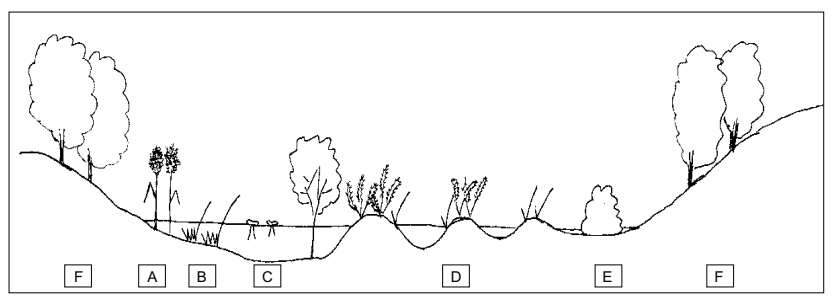

Fig. 4. Transect of actual vegetation around Lago Trifoglietti. A: Sparganium erectum; B: Carex vesicaria; C: Potamogeton natans, $P$. nodosus and Alnus cordata trees; D: Carex paniculata, Osmunda regalis; E: Carex pendula, Mentha aquatica, Rubus ulmifolius; F: Fagus.

A schematic transect of present-day vegetation is presented in Fig. 4. The lake vegetation comprises of a mosaic of different plant communities, partly linked with dynamic successions due to variations in water level and soil composition.

Most of the lake surface is occupied by a Carex paniculata swamp (D). This tall sedge grows in spaced tussocks protruding from the water surface, the living plant progressively builds up around a small peaty hill, often covered by a carpet of Sphagnum palustre and Aulacomnium palustre. Between tussocks the water attains a depth of $60 \mathrm{~cm}$, and since vegetal fibres accumulate in the ground, which tends to dry up, the sedge is, therefore, progressively invaded by other helophyte and mesophyte species. In shallow areas (E), Carex paniculata develops with Osmunda regalis, Angelica sylvestris, Carex pendula and nemoral herbs such as Lysimachia nemorum, Arisarum proboscideum and Oxalis acetosella. The littoral mires are invaded by Rubus hirtus and R. ulmifolius (E) and two isolated bushy communities of Salix caprea very near the surrounding beech forest $(\mathrm{F})$.

From the centre of the lake to the southern edge, the depth increases and the open surface is discontinuously colonised by communities of Potamogeton natans (C). The lake's western shore is supplied by the rills, where a belt of vegetation is found characterised by Sparganium erectum (A). Alisma plantago-aquatica and Ranunculus fontanus are rare in this community, the sedge bed being dominated by Carex vesicaria (B) within the belt and outside of the peaty soil.

A limited stand of Alnus cordata (C) develops near the lake centre (deeper water) and appears to be in regression. We hypothesise that this tree species grew in the sunniest area around the lake when the marshes were in a dry phase. The anthropogenic rise in water depth, however, is not compatible with the alder's ecological needs. The importance of Lago Trifoglietti depends on the presence of the endemic amphibians and on endangered aquatic and hygrophilous habitats in the Mediterranean area (Sperone et al., 2007). The dam, thus, provides the appropriate water depth ensuring continuity of all interesting aquatic habitats and species. The increasing depth, however, has certainly submerged and damaged species such as Sphagnum palustre and Osmunda regalis.

\section{Methods}

\subsection{Core sampling and sedimentology}

Coring was undertaken using a $1 \mathrm{~m}$ long Russian peat corer with a $6.3 \mathrm{~cm}$ diameter. Three cores were taken (S1, S2 and S3; Fig. 2b) along a transect from centre of the lake toward the northeastern shore to find a sediment sequence capable of documenting the entire Holocene in high resolution. Thus, the core S2 sequence was chosen for laboratory investigation and was obtained from twin cores taken from the lake's north-east edge. Segments were extracted on site, wrapped in plastic, transported to the University of Franche-Comté and stored at $4{ }^{\circ} \mathrm{C}$.

The cores were split longitudinally into two halves, photographed and logged with a GEOTEK Multi Sensor Core Logger in order to obtain geophysical measurements (scanning of lithology, measurements of magnetic susceptibility, MS) at $1 \mathrm{~cm}$ intervals. The master core (MC) was established based on lithological changes (with observation of key reference horizons) in combination with MS profiles. This study, thus, refers to the MC constructed from the twin cores (S2A and S2B).

The MS, mainly dependent on magnetite concentration in sediments, was measured in electromagnetic units to determine the inorganic allochthonous sediment content (Gedye et al., 2000). As the development of pedogenesis under forest cover may have favoured a mineral magnetic increase in soils (de Jong et al., 1998), low MS recorded in sediments is to be expected during phases of stabilised vegetated slopes (Whitlock et al., 2011), while increased magnetic concentrations may be related to changes in sediment sources and to erosive processes of soils (Dearing et al., 1996; de Jong et al., 1998; Vannière et al., 2003; Cruise et al., 2009). Nevertheless, when ferrimagnetic mineral concentration is low (magnetite and maghaemite), the value of MS may be largely influenced by diamagnetic minerals (quartz, carbonates) (Thompson and Oldfield, 1986).

\subsection{Radiocarbon dating}

The chronology is based on 11 Accelerator Mass Spectrometry (AMS) ${ }^{14} \mathrm{C}$ ages measured on terrestrial organic material (Table 1). The radiocarbon ages have been calibrated in yr cal BP by using Calib 6.0 software (Stuiver and Reimer, 1993) based on calibration curve IntCal09 (Reimer et al., 2009). Dates are expressed as intercepts with $2 \sigma$ ranges. To confirm this chronology, the base of the core $(843 \mathrm{~cm}$ depth, Table 1) was dated a second time and provides a similar age $(9850 \pm 50 \mathrm{BP}$ and $9940 \pm 60 \mathrm{BP})$. The age-depth model (Fig. 5) is constructed using a mixed-effect regression model according to the procedure standardised by Heegaard et al. (2005). 
Table 1. AMS-radiocarbon dates with $2 \sigma$ range of calibration from Lago Trifoglietti's S2A and S2B cores.

\begin{tabular}{lccrrr}
\hline Sample ID & Lab. code & Material & $\begin{array}{r}\text { AMS }{ }^{14} \mathrm{C} \\
\text { Age BP }\end{array}$ & $\begin{array}{r}\text { Depth } \\
\text { MC }(\mathrm{cm})\end{array}$ & $\begin{array}{r}\text { cal yr BP } \\
(2 \sigma)\end{array}$ \\
\hline S4-A1 & POZ-33804 & Wood-Charcoal & $125 \pm 30$ & 87 & $0-270$ \\
S4-A2 & POZ-33806 & Wood-Charcoal & $2675 \pm 35$ & 172 & $2740-2850$ \\
S4-A3 & POZ-33807 & Wood-Charcoal & $3970 \pm 40$ & 295 & $4290-4530$ \\
S4-A4 & POZ-33808 & Wood-Charcoal & $4890 \pm 35$ & 371 & $5580-5710$ \\
S4-A5 & POZ-33809 & Wood-Charcoal & $6660 \pm 50$ & 497 & $7430-7610$ \\
S4-A6 & POZ-33810 & Wood-Charcoal & $7920 \pm 50$ & 571 & $8600-8980$ \\
S4-A7 & POZ-33811 & Wood-Charcoal & $8600 \pm 50$ & 685 & $9490-9680$ \\
S4-A8 & POZ-33812 & Wood-Charcoal & $9335 \pm 60$ & 761 & $10290-10710$ \\
S4-A9 & POZ-33813 & Wood-Charcoal & $9630 \pm 60$ & 806 & $10760-11190$ \\
S4-B9 & POZ-41168 & Wood-Charcoal & $9850 \pm 50$ & 843 & $11190-11388$ \\
S4-B9 & POZ-33876 & Wood-Charcoal & $9940 \pm 60$ & 843 & $11220-11690$ \\
\hline
\end{tabular}

\subsection{Pollen analysis}

\subsubsection{Surface samples}

Studying the relationship between pollen rain and actual vegetation is essential for the interpretation of fossil pollen spectra. The pollen rain depends primarily on the internal parameters of the plant (production potential and dispersion) and external factors (topography and climate). Barthelemy and Jolly (1989) consider that the most important factor is the topography: the wind that rises along the slope, carrying the pollen that falls to the ground where the slope is interrupted by a shelf. The deposit is then behind the edge of the shelf into the basin (Brugiapaglia et al., 1998). At Trifoglietti, the filter effect operated by the dense forest vegetation that surrounds the lake is also taken into account. In order to interpret the fossil diagram, five moss samples were collected (Fig. 2b) and treated both chemically ( $\mathrm{NaOH}, \mathrm{HCl}, \mathrm{HF}$, acetolysis) and physically (sieving 300 and $180 \mu \mathrm{m}$ ). To emphasise the correlation between pollen rain and vegetation, we provide the corresponding phytosociological relevés of actual vegetation (Pignatti, 1953) (Table 2) along with the five surface samples, using the TILIA 1.12 programme. A pollen diagram of selected taxa from surface samples is provided in Fig. 6.

\subsubsection{Pollen samples}

Sediment samples of $1 \mathrm{~cm}^{3}$ of sediments were treated both chemically ( $\mathrm{HCl}, \mathrm{KOH}, \mathrm{HF}$, acetolysis) and physically (sieving) following standard procedures (Moore et al., 1991). $L y$ copodium tablets were added for estimating pollen concentrations (grains $\mathrm{cm}^{-3}$ ). Samples were taken at four centimetres resolution on the $8.5 \mathrm{~m}$ of the core. A total of 170 pollen samples were analysed under a light microscope at a standard magnification of $\times 400.178$ pollen types were identified using photo atlases (Reille, 1992-1998; Beug, 2004) and the reference collection at the University of Franche-Comté. A sum of at least 300 terrestrial pollen grains was counted, excluding dominant terrestrial taxa along with water and wetland plants, as well as pteridophyte spores. Percentages were calculated based on the total pollen sum.

Using the TILIA 1.12 programme, a pollen diagram of selected taxa is provided in Fig. 7. Local pollen assemblage zones (LPAZ) were defined according to the CONISS function of the TILIA 1.12 programme. Two drawn and twelve dashed lines define limits between statistically firstand second-order splits. Table 3 sums the main, common and rare pollen types in each LPAZ. In order to describe vegetation changes, taxa have been grouped according to their present-day ecology, with the help of field observation and according to their affinities with human-induced activities. Figure 7 represents taxa as follows (from left to right): trees, total Arboreal Pollen $\left(\mathrm{AP}_{\mathrm{t}}\right)$, plants from openland vegetation, anthropogenic indicators (Apiaceae, Apium, Meum, Peucedanum tp., Bupleurum tp., Plantago, Plantago major/P. media, Cannabaceae, Urticaceae, Papaver, Linum) and Cerealia tp. (Cereal tp. 40-60 $\mu \mathrm{m}$, Triticum, Secale tp.). All pollen taxa percentages have been calculated according to the total counted terrestrial pollen grains. Figure 8 presents a simplified pollen diagram with major arboreal and nonarboreal taxa and the sum of anthropogenic indicators.

Hygrophilous plants have been placed separately in the illustrations (Table 3; Figs. 7 and 8). They are composed of aquatics (pollen: Cyperaceae, Carex tp., Scirpus tp., Cyperus tp. Alisma, Ceratophyllum sp., Cladium mariscus, Lysimachia, Mentha, Myriophyllum, Nymphaeaceae, Ranunculaceae tp. Batrachium, Sparganium, Typha latifolia, Typha minima, Lythrum), of spore producers (Osmunda), of pollen producer (Ast. Asteroideae Eupatorium) and of algae (Botryococcus). Spores and algae have been added to the total counted palynomorphs in order to calculate their percentage. As modern alder development is mostly related to the lake environment, Alnus has, therefore, been placed together with the hygrophilous taxa in Fig. 8. In Table 3 and Figs. 7-8, an additional rate of arboreal pollen without Alnus $\left(\mathrm{AP}_{\mathrm{wa}}\right)$ 
has been calculated by excluding main hygrophilous taxa (Aquatics and Eupatorium) from the NAP.

\subsubsection{Pollen-based climate reconstruction}

A multi-method approach of the Trifoglietti pollen sequence is applied in order to provide robust quantitative estimates of the Holocene climate and to better assess reconstruction error. We have chosen two "standard" methods based on different ecological concepts: the Modern Analogues Technique (MAT, Guiot, 1990), and the Weighted Average Partial Least Squares regression (WAPLS, ter Braak and Juggins, 1993). These methods are usually applied to reconstruct climate changes in Mediterranean area during the Lateglacial or the Holocene (e.g., Davis and Brewer, 2009; Dormoy et al., 2009; Di Donato et al., 2008; Joannin et al., 2011, 2012; Peyron et al., 2011; Combourieu Nebout et al., 2012). The WAPLS NMDS/GAM is a true transfer function based on a calibration between environmental variables and modern pollen assemblages whereas the MAT does not require real calibration. This method is based on a comparison of past assemblages to modern pollen assemblages and used a modern pollen dataset that contains more than 3500 modern spectra (Dormoy et al., 2009) and in which surface sample spectra from Lago Trifoglietti surroundings, from Mount Altesina (close to Lake Pergusa, Sicily) and Lake Preola (Sicily) have been included. Annual precipitations (MAT Pann, WAPLS Pann) have been reconstructed and represented in Fig. 9f. Winter and summer precipitations are also reconstructed and discussed in the paper of Peyron et al. (2012) which propose a climatic reconstruction based on a multi-method approach (MAT, WA, WAPLS, NMDS/GAM) on four Italian pollen records (Lakes Ledro, Accesa, Trifoglietti, Pergusa). More details on the methods and their application to Trifoglietti's pollen record are given in this paper. Note that Alnus is excluded in the climate reconstructions performed with both the MAT and the WAPLS and that the values of precipitation calculated for the surface samples taken close to the Trifoglietti site have been corrected according to the ombrothermic diagram of the closest meteorological station $(1850 \mathrm{~mm})$.

\section{Results and interpretation}

\subsection{Sediment and age model}

\subsubsection{Lithological and magnetic susceptibility changes}

Gyttja and peaty sediments are the main components of core S2 at Trifoglietti (Fig. 7). The stratigraphy was as follows:

- from 850 to $843 \mathrm{~cm}$ : gyttja layer,

- from 843 to $805 \mathrm{~cm}$ : silt layer,

- from 805 to $700 \mathrm{~cm}$ : mixed gyttja and silt layer,

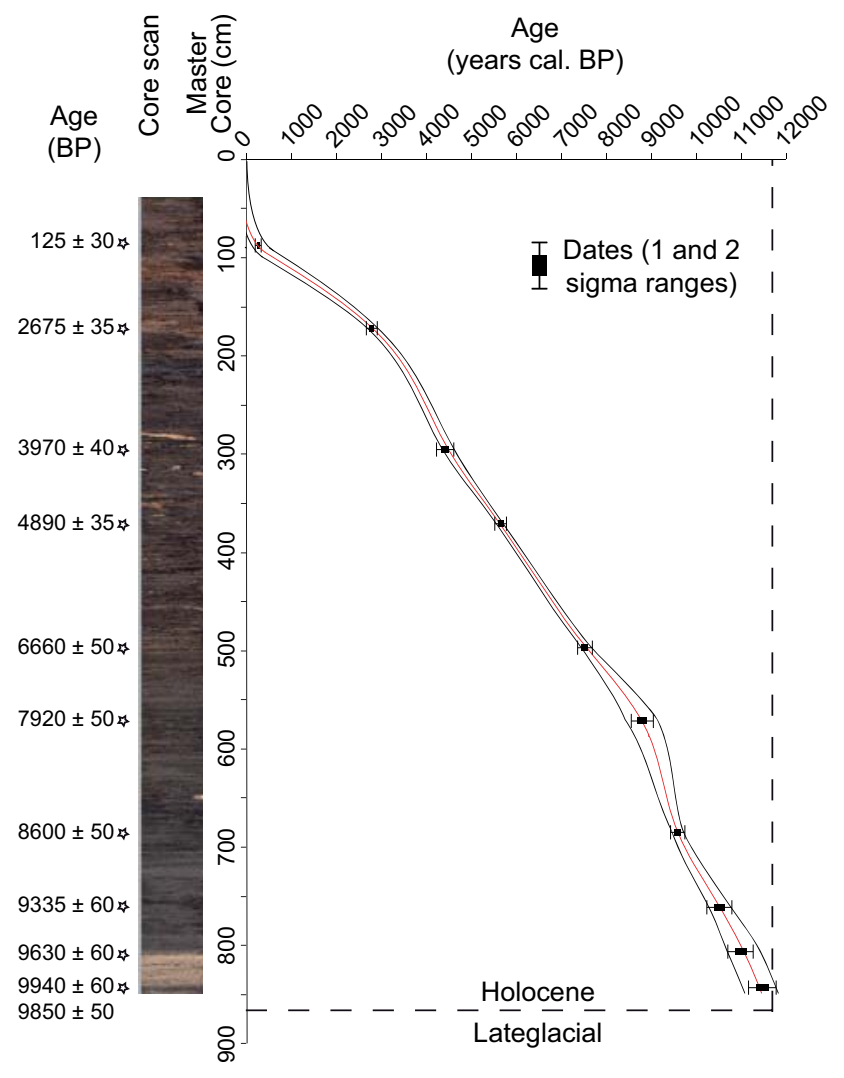

Fig. 5. Lithology and age-depth model of mastercore based on radiocarbon calibrated ages (AMS, see Table 1).

- from 700 to $530 \mathrm{~cm}$ : gyttja layer interrupted by a silt layer from 595 to $548 \mathrm{~cm}$,

- from 530 to $482 \mathrm{~cm}$ : dark peaty deposits,

- from 482 to $380 \mathrm{~cm}:$ gyttja/peat layer,

- from $380 \mathrm{~cm}$ to the top: deposits are characterised by an alternation of peat and dark peat sediments that include thin gyttja layers (292-289, 213-200 and 100$97 \mathrm{~cm})$ and gyttja/silt layers $(162-152,122-117$ and $107-100 \mathrm{~cm})$.

In general, MS values measured in gyttja and peat sediments are low (Figs. 7 and 8). However, three major peaks are observed with strong values in the silt deposit at 844$804 \mathrm{~cm}$, in a woody-remains layer at $173-169 \mathrm{~cm}$, and in a silt layer at $122-117 \mathrm{~cm}$. In this last level, strong MS values are not explained as no volcanic minerals have been found.

\subsubsection{Age-depth model}

The two radiocarbon dates obtained for depth $843 \mathrm{~cm}$ provided consistent similar ages and indicate an early Holocene age for the basal part of the silt layer recorded from 840 to $805 \mathrm{~cm}$ depth. The age-depth curve (Fig. 5) evidences a broadly constant sedimentation rate from the beginning of 
the Holocene up to around $3000 \mathrm{cal} \mathrm{BP}$, giving an average temporal resolution of about $60 \mathrm{yr} / \mathrm{sample}$. The rate decreases upwards. The average temporal resolution is estimated at ca. $70 \mathrm{yr} / \mathrm{sample}$ for the entire Holocene and attains a maximum of $37 \mathrm{yr} / \mathrm{sample}$ for the period 10000 9000 cal BP.

\subsection{Pollen analysis}

\subsubsection{Surface samples}

The five surface samples represent the different vegetation types that grow around the lake and contribute to the interpretation of the fossil pollen spectra. The pollen sum is about 500 grains $(\mathrm{AP}+\mathrm{NAP})$ per surface sample.

Lago Trifoglietti pollen rain broadly mimics the corresponding types of vegetation: in fact the filter effect, therefore, determines that the regional pollen rain is poorly recorded, while a good assessment of the local vegetation is well demonstrated by the results obtained in the diagram (Fig. 6). On the whole, the Pinus abundance recorded in open land $(3 \%)$ is in better accordance with reality than in $\mathrm{Fa}$ gus wood (1\%). Pollen grains of Quercus robur tp., Olea and Castanea are produced by plants absent (almost absent in the case of Castanea) from around the lake. Pollen catchment is likely to include lower-altitude vegetation signals due to the topography of the Catena Costiera Mountains and by ascending air flow along the slopes. Hygrophilous vegetation with Carex (relevés 1 and 2) is represented with over $40 \%$ of Cyperaceae. The Osmunda percentages (10-30\%) are in accordance with the Osmunda vegetation (20-60\%). Lysimachia vulgaris is represented by 10 to $30 \%$ of pollen. Angelica pollen is recorded by 1 to $15 \%$. Eupatorium pollen is present from 1 to $5 \%$. The trees of Alnus cordata are overrepresented in the pollen rain (10-30\%). The transition of lake vegetation to Fagus vegetation (relevé 3) is dominated by Rubus and Carex, which are, however, under-represented in the pollen rain $(<1 \%)$. Fagus and Alnus cordata are normally and over-represented, respectively. The Fagus wood (relevé 4) is well represented $(60 \%)$, whereas the other species are under-represented though Alnus cordata is overrepresented (15\%). Under trees of Alnus cordata (relevé 5), this pollen grain is over-represented $(70 \%)$ while the scrub vegetation is under-represented (Erica, $2 \%$; Clematis, $2 \%$ ).

Pollen rain from relevés 1 and 2 faithfully reproduce the hygrophilous vegetation associated with the wet environment of Lago Trifoglietti while relevés 3 and 4 represent terrestrial vegetation (i.e., mixed beech-oak forest) growing independently of the lake.

\subsubsection{Pollen sequence and terrestrial vegetation dynamics}

According to the ${ }^{14} \mathrm{C}$ dates, the sequence starts with the beginning of the Holocene (zone T-1, <11 400 cal BP; Table 3).
The pollen record identifies the regional presence of Fagus, Abies, Ostrya and several temperate trees. Although Quercus robur tp. and Fagus pollen grains are abundant (more than 25 and $10 \%$, respectively), NAP percentages (ca. $60 \%$ ), diversity of herbaceous taxa and occurrences of Juniperus and Ephedra all indicate that the site is likely to have remained above the timberline at this time, surrounded by oroMediterranean meadows. The decrease of AP percentages could be due either to a lowering of the tree limit or to a poor pollen productivity of the temperate trees as a consequence of the cooling. Oaks and Fagus were likely not far off, on the steep slopes between the sea and the lake $(9 \mathrm{~km}$ from Cetrano, on the seaside). Ascending winds from the west probably explain the high amount of well-dispersed oak pollen at Trifoglietti.

From ca. 11400 to ca. $11000 \mathrm{cal}$ BP (zone T-2), an increase in percentages of Cichorioideae, Caryophyllaceae and Artemisia suggest a strong cooling. NAP reach $75 \%$ and suggest that the site may have been above the timberline at that time, with a long persistence of meadows during the early Holocene at the Trifoglietti altitude. In spite of the cooling, Abies expands slightly. Noteworthy also is the quasiabsence of Pinus during the early Holocene (the percentages are lower than $10 \%$ in T-1 and T-2, and even less after 11000 cal BP). The few pollen grains observed must correspond to a wind transport, possibly from the Mediterranean belt. But less than $100 \mathrm{~km}$ to the north, in mountains such as the Pollino Ridge, biogeographers have described populations of an indigenous Pinus nigra subsp. laricio (Conti et al., 2005; Tomaselli, 2007). These endemic trees must have occupied extremely restricted surfaces at least since the end of the Last Glacial. If so, as mentioned in the case of Corsica today (Reille, 1992-1998), the absence of subalpine tree species may explain a relatively low timberline.

At around $11000 \mathrm{cal}$ BP (zone T-3) the rapid increase in Fagus corresponds to the local establishment of a mountain forest ecosystem dominated by Fagus and Abies trees. High values of AP suggest that the site is now below the timberline. Abies percentages also increase progressively to ca. $20 \%$ and always remain lower than those of Fagus. Nevertheless, regular occurrences of Abies stomata ensure that the trees grew alongside Fagus in the lake's immediate surroundings. Considering the poor dispersal of Abies pollen grains (Mazier, 2006), this conifer was probably as abundant as Fagus. The present Fagus (beech) forest is directly inherited from the remote early Holocene, thus, furnishing a rare example of beech woodstands maintained in the same place for more than $11000 \mathrm{yr}$. The beech forests or stands, nowadays scattered across the mountain belt from the Central Apennines to Madonie Mountains in Sicily, are the relics of a long continuous presence as confirmed by genetic inheritance (Magri et al., 2006).

CONISS software identifies three subzones (Table 3). The first is characterised by relatively abundant oak pollen grains and increased Ostrya/Carpinus orientalis pollen grains, 
Table 2. Relevé of vegetation from the peat/lake numbered 1 to 3, and from the surrounding forest of Fagus (4) and maquis with Alnus cordata (5). Codification of surface sample cover is as follows: $5=100-80 \% ; 4=80-60 \% ; 3=60-40 \% ; 2=40-20 \% ; 1=20-1 \% ;+=<1 \%$.

\begin{tabular}{|c|c|c|c|c|c|}
\hline & $\begin{array}{c}1 \\
\text { Carex } \\
\text { paniculata } \\
\text { vegetation }\end{array}$ & $\begin{array}{c}2 \\
\text { Carex } \\
\text { paniculata } \\
\text { vegetation }\end{array}$ & $\begin{array}{c}3 \\
\text { Transition } \\
\text { lake } \\
\text { vegetation } \\
\text { to Fagus } \\
\text { slvatica } \\
\text { wood }\end{array}$ & $\begin{array}{c}4 \\
\text { Fagus } \\
\text { sylvatica } \\
\text { wood }\end{array}$ & $\begin{array}{c}5 \\
\text { Transition } \\
\text { maquis to } \\
\text { Alnus } \\
\text { cordata } \\
\text { wood }\end{array}$ \\
\hline Surface $\mathrm{m}^{2}$ & 5 & 5 & 5 & 20 & 50 \\
\hline Herbaceous layer cover & 100 & 100 & 90 & 100 & 100 \\
\hline Depht of water $\mathrm{cm}$ & 60 & 50 & 10 & & \\
\hline Carex paniculata & 5 & 5 & & & \\
\hline Osmunda regalis & 2 & 3 & 1 & & \\
\hline Angelica sylvestris & 1 & 1 & & & \\
\hline Lysimachia vulgaris & + & 1 & & & \\
\hline Eupatorium cannabinum & + & 1 & & & \\
\hline Oxalis acetosella & + & 1 & & & \\
\hline Rubus hirtus & + & + & & & \\
\hline Lycopus europaeus & + & + & + & & \\
\hline Solanum dulcamara & + & & & & \\
\hline Alnus cordata & + & & & & 1 \\
\hline Athyrium filix-foemina & + & & + & & \\
\hline Lonicera sp. & + & & & & \\
\hline Holcus lanatus & & + & & & \\
\hline Arisarum proboscideum & & + & & & \\
\hline Carex distans & & 1 & & & \\
\hline Mentha aquatica & & + & 1 & & \\
\hline Carex acutiformis & & & 2 & & \\
\hline Rubus ulmifolius & & & 2 & & \\
\hline Carex pendula & & & 1 & & \\
\hline Fagus sylvatica & & & 1 & 5 & \\
\hline Vinca minor & & & & 4 & \\
\hline Cyclamen hederifolium & & & & 2 & \\
\hline Polysticum aculeatum & & & & 1 & \\
\hline Pinus nigra subsp. laricio & & & & + & \\
\hline Erica arborea & & & & & 3 \\
\hline Cistus salvifolius & & & & & 2 \\
\hline Helichrysum italicum & & & & & 2 \\
\hline Sarothamnus scoparius & & & & & 2 \\
\hline Clematis vitalba & & & & & 1 \\
\hline
\end{tabular}

Trifoglietti

surface samples

selected pollen types, \% values

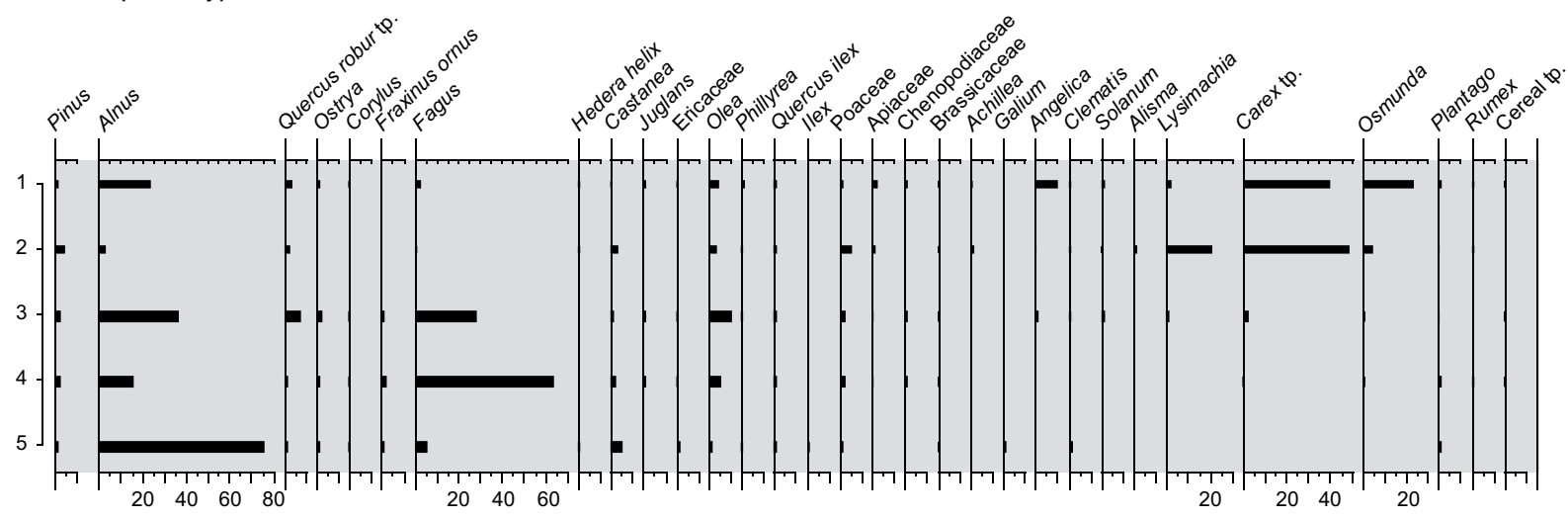

Fig. 6. Pollen diagram of five surface samples (see location map, Fig. 2b). 


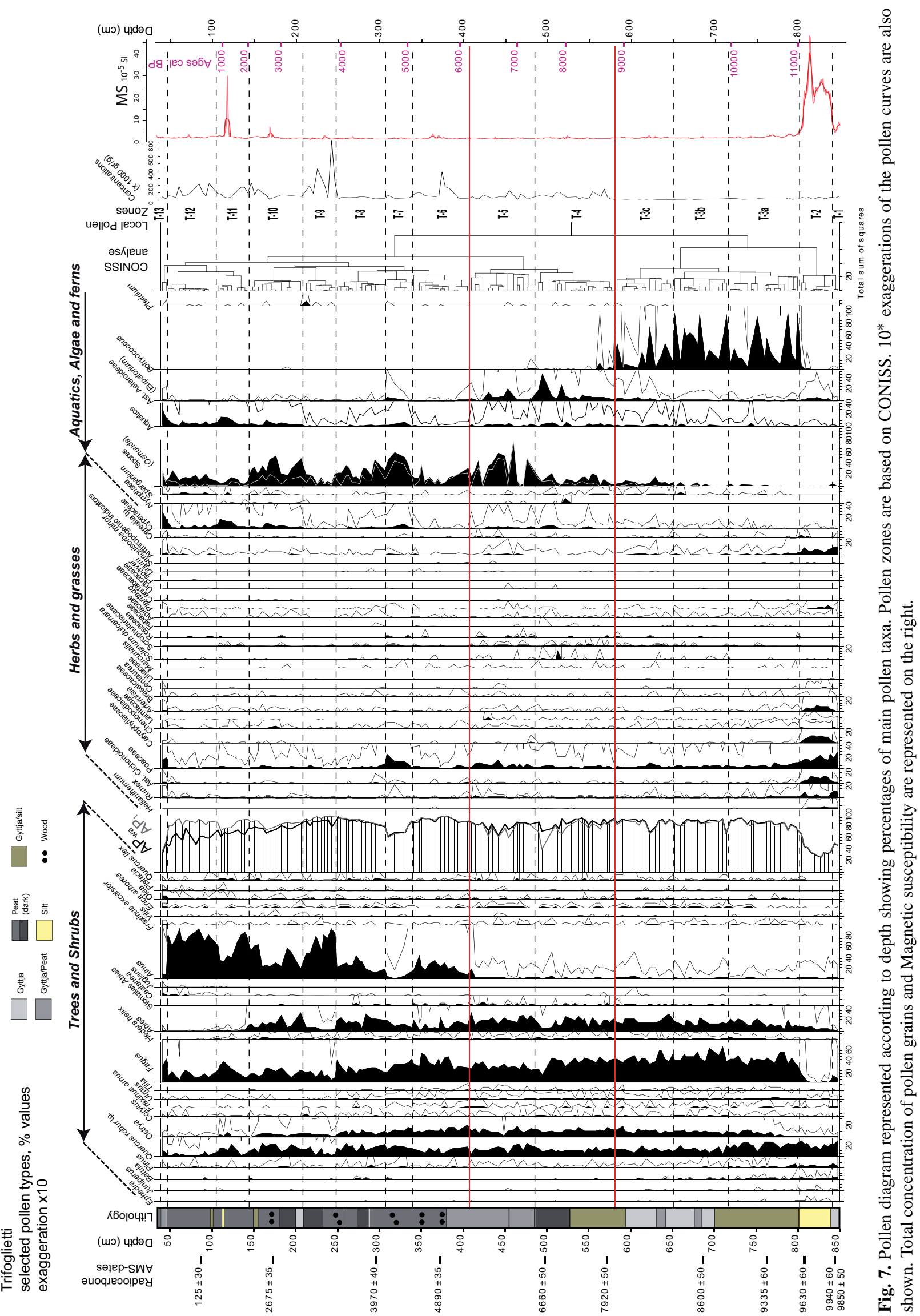


Table 3. Inventory of local pollen zones with depth and estimated ages, main taxa, total of arboreal pollen (AP), common and rare pollen types and palynomorphs used for hygrophilous vegetation. Note that two ratios $\mathrm{AP}_{\mathrm{t}}$ and $\mathrm{AP}_{\mathrm{wa}}$ are used (arboreal pollen without $A$ lnus $\left(\mathrm{AP}_{\mathrm{wa}}\right)$ has been calculated by excluding main hygrophilous taxa - Aquatics and Eupatorium - of the NAP).

\begin{tabular}{|c|c|c|c|c|c|}
\hline LPAZ & $\begin{array}{l}\text { Depth }(\mathrm{cm}) \\
\text { Age }(\text { yr cal } \\
\text { BP) }\end{array}$ & $\begin{array}{l}\text { Main taxa } \\
\text { observed }\end{array}$ & $\begin{array}{l}\text { Total of } \\
\text { Arboreal } \\
\text { Pollen \% }\end{array}$ & $\begin{array}{l}\text { Common pollen types }(\mathrm{CPT}) \\
\text { Rare pollen types (RPT) }\end{array}$ & Palynomorphs \\
\hline $\mathrm{T}-13$ & $\begin{array}{l}46-40 \\
33-0\end{array}$ & Fagus & $\begin{array}{l}\mathrm{AP}_{\mathrm{t}} 60 \\
\mathrm{AP}_{\mathrm{wa}} 40\end{array}$ & $\begin{array}{l}\text { CPT: Deciduous Quercus, Ostrya, Castanea, Alnus, } \\
\text { Olea, Poaceae, Cyperaceae } \\
\text { RPT: Abies, Juglans, Fraxinus excelsior, Erica arborea, } \\
\text { Pistacia, Quercus ilex, Rumex, Ast. Asteroideae }\end{array}$ & $\begin{array}{l}\text { Osmunda and aquatics } \\
\text { development }\end{array}$ \\
\hline $\mathrm{T}-12$ & $\begin{array}{l}106-46 \\
800-33\end{array}$ & Fagus-Alnus & $\begin{array}{l}\mathrm{AP}_{\mathrm{t}} 88-98 \\
\mathrm{AP}_{\mathrm{wa}} 50-78\end{array}$ & $\begin{array}{l}\text { CPT: Deciduous Quercus, Ostrya, Olea, Cyperaceae } \\
\text { RPT: Corylus, Castanea, Juglans, Pistacia, Quercus } \\
\text { ilex, Rumex, Poaceae }\end{array}$ & $\begin{array}{l}\text { Osmunda and aquatics } \\
\text { reduction }\end{array}$ \\
\hline $\mathrm{T}-11$ & $\begin{array}{l}144-106 \\
2100-800\end{array}$ & $\begin{array}{l}\text { Fagus-deciduous } \\
\text { Quercus-Alnus }\end{array}$ & $\begin{array}{l}\mathrm{AP}_{\mathrm{t}} 88-98 \\
\mathrm{AP}_{\mathrm{wa}} 68-80\end{array}$ & $\begin{array}{l}\text { CPT: Ostrya, Quercus ilex, Poaceae, Cyperaceae } \\
\text { RPT: Hedera helix, Abies, Olea, Ast. Asteroideae }\end{array}$ & $\begin{array}{l}\text { Osmunda and aquatics } \\
\text { development }\end{array}$ \\
\hline $\mathrm{T}-10$ & $\begin{array}{l}210-144 \\
3500-2100\end{array}$ & $\begin{array}{l}\text { Fagus-deciduous } \\
\text { Quercus-Abies- } \\
\text { Alnus }\end{array}$ & $\begin{array}{l}\mathrm{AP}_{\mathrm{t}} 75-95 \\
\mathrm{AP}_{\mathrm{wa}} 67-88\end{array}$ & $\begin{array}{l}\text { CPT: Ostrya, Hedera helix, Poaceae, Cyperaceae } \\
\text { RPT: Pinus, Olea, Quercus ilex, Ast. Asteroideae }\end{array}$ & $\begin{array}{l}\text { Osmunda and aquatics } \\
\text { development }\end{array}$ \\
\hline $\mathrm{T}-9$ & $\begin{array}{l}246-210 \\
3950-3500\end{array}$ & Fagus-Alnus & $\begin{array}{l}\mathrm{AP}_{\mathrm{t}} 90-98 \\
\mathrm{AP}_{\text {wa }} 81-90\end{array}$ & $\begin{array}{l}\text { CPT: Ostrya, deciduous Quercus, Abies, Poaceae } \\
\text { RPT: Hedera helix, Olea, Quercus ilex, Cyperaceae, } \\
\text { Ast. Asteroideae }\end{array}$ & $\begin{array}{l}\text { Osmunda reduction, rare } \\
\text { aquatics and Pteridium }\end{array}$ \\
\hline $\mathrm{T}-8$ & $\begin{array}{l}308-246 \\
4650-3950\end{array}$ & $\begin{array}{l}\text { Fagus-deciduous } \\
\text { Quercus-Abies- } \\
\text { Alnus }\end{array}$ & $\mathrm{AP}_{\mathrm{t}} 80-95$ & $\begin{array}{l}\text { CPT: Ostrya, Alnus, Poaceae, Cyperaceae } \\
\text { RPT: Betula, Hedera helix, Erica arborea, Quercus ilex, } \\
\text { Ast. Asteroideae }\end{array}$ & $\begin{array}{l}\text { Osmunda and aquatics } \\
\text { reduction }\end{array}$ \\
\hline $\mathrm{T}-7$ & $\begin{array}{l}338-308 \\
5100-4650\end{array}$ & $\begin{array}{l}\text { Fagus-deciduous } \\
\text { Quercus-Abies }\end{array}$ & $\mathrm{AP}_{\mathrm{t}} 65-80$ & $\begin{array}{l}\text { CPT: Ostrya, Alnus, Poaceae, Cyperaceae } \\
\text { RPT: Ulmus, Hedera helix, Olea, Quercus ilex, Rumex, } \\
\text { Ast. Asteroideae }\end{array}$ & $\begin{array}{l}\text { Osmunda and aquatics } \\
\text { development }\end{array}$ \\
\hline T-6 & $\begin{array}{l}408-338 \\
6150-5100\end{array}$ & $\begin{array}{l}\text { Fagus-deciduous } \\
\text { Quercus-Alnus- } \\
\text { Ostrya }\end{array}$ & $\mathrm{AP}_{\mathrm{t}} 85-98$ & $\begin{array}{l}\text { CPT: Abies, Hedera helix } \\
\text { RPT: Pinus, Ulmus, Olea, Quercus ilex, Rumex, } \\
\text { Poaceae, Cyperaceae, Ast. Asteroideae }\end{array}$ & $\begin{array}{l}\text { Osmunda and aquatics } \\
\text { reduction }\end{array}$ \\
\hline $\mathrm{T}-5$ & $\begin{array}{l}484-408 \\
7300-6150\end{array}$ & $\begin{array}{l}\text { Fagus-deciduous } \\
\text { Quercus-Abies- } \\
\text { Ostrya }\end{array}$ & $\mathrm{AP}_{\mathrm{t}} 65-92$ & $\begin{array}{l}\text { CPT: Hedera helix, Alnus, Fraxinus excelsior, Quercus } \\
\text { ilex, Rumex, Poaceae, Cyperaceae, Ast. Asteroideae } \\
\text { RPT: Fraxinus ornus, Tilia, Corylus, Olea, Lamiaceae, } \\
\text { Scrophulariaceae, Rosaceae, Cerealia tp. }\end{array}$ & Osmunda and aquatics \\
\hline $\mathrm{T}-4$ & $\begin{array}{l}654-580 \\
9400-8900\end{array}$ & $\begin{array}{l}\text { Fagus-deciduous } \\
\text { Quercus-Abies- } \\
\text { Ostrya }\end{array}$ & $\begin{array}{l}\mathrm{AP}_{\mathrm{t}} 40-93 \\
\mathrm{AP}_{\mathrm{wa}} 71-93\end{array}$ & $\begin{array}{l}\text { CPT: Ulmus, Corylus, Fraxinus ornus, Hedera helix, } \\
\text { Quercus ilex, Poaceae, Solanum dulcamara, } \\
\text { Scrophulariaceae, Ast. Asteroideae } \\
\text { RPT: Erica arborea, Rumex, Rosaceae }\end{array}$ & $\begin{array}{l}\text { Osmunda and aquatics } \\
\text { development }\end{array}$ \\
\hline $\mathrm{T}-3 \mathrm{c}$ & $\begin{array}{l}654-580 \\
9400-8900\end{array}$ & & & $\begin{array}{l}\text { CPT: Hedera helix, Alnus, Erica arborea, Poaceae } \\
\text { RPT: Betula, Ulmus, Castanea, Olea, Rumex, } \\
\text { Scrophulariaceae, Cyperaceae, Ast. Asteroideae }\end{array}$ & \\
\hline $\mathrm{T}-3 \mathrm{~b}$ & $\begin{array}{l}720-654 \\
10000-9400\end{array}$ & & & $\begin{array}{l}\text { CPT: Betula, Corylus, Ulmus, Erica arborea, Hedera } \\
\text { helix, Poaceae } \\
\text { RPT: Pistacia, Rumex, Cyperaceae, Ast. Asteroideae }\end{array}$ & \\
\hline T-3a & $\begin{array}{l}804-720 \\
11000-10000\end{array}$ & & & $\begin{array}{l}\text { CPT: Ulmus, Betula, Pinus, Hedera helix, Poaceae, } \\
\text { Rumex } \\
\text { RPT: Fraxinus ornus, Quercus ilex }\end{array}$ & \\
\hline $\mathrm{T}-3$ & $\begin{array}{l}804-580 \\
11000-8900\end{array}$ & $\begin{array}{l}\text { Fagus-deciduous } \\
\text { Quercus-Abies- } \\
\text { Ostrya }\end{array}$ & $\mathrm{AP}_{\mathrm{t}} 80-95$ & & $\begin{array}{l}\text { Botryococcus (algae) is } \\
\text { strongly developed } \\
\text { despite a marked } \\
\text { variability }\end{array}$ \\
\hline $\mathrm{T}-2$ & $\begin{array}{l}842-804 \\
11400-11000\end{array}$ & $\begin{array}{l}\text { deciduous } \\
\text { Quercus- } \\
\text { Poaceae- } \\
\text { Caryophyllaceae- } \\
\text { Artemisia }\end{array}$ & $\mathrm{AP}_{\mathrm{t}} 25-40$ & $\begin{array}{l}\text { CPT: Betula, Pinus, Abies, Helianthemum, Rumex, Ast. } \\
\text { Cichorioideae, Chenopodiaceae, Plantago, Ast. } \\
\text { Asteroideae } \\
\text { RPT: Juniperus, Ulmus, Alnus, Centaurea, Lamiaceae }\end{array}$ & \\
\hline $\mathrm{T}-1$ & $\begin{array}{l}850-842 \\
\text { Before } 11400\end{array}$ & $\begin{array}{l}\text { deciduous } \\
\text { Quercus-Fagus- } \\
\text { Poaceae }\end{array}$ & $\mathrm{AP}_{\mathrm{t}} 50-55$ & $\begin{array}{l}\text { CPT: Betula, Pinus, Alnus, Helianthemum, Rumex, Ast. } \\
\text { Cichorioideae, Chenopodiaceae } \\
\text { RPT: Abies, Fraxinus ornus, Artemisia, Plantago, Ast. } \\
\text { Asteroideae }\end{array}$ & \\
\hline
\end{tabular}


indicating that the oak belt must have been closer on the mountain slope. In spite of the vicinity of the Mediterranean belt, sclerophyllous taxa (Olea, Quercus ilex type) which appear at the beginning of zone T-3 are scarce (which will be the case until the top of the sequence). Their pollen transportation by ascending winds was not efficient here. Three hypotheses may explain this evidence: (1) due to the steep slope, the surface occupied by the Mediterranean belt was limited to a narrow fringe near the sea, unable to produce and disperse a large quantity of pollen grains, (2) westerly winds from the sea brought heavy rainfall to the Catena Costiera Mountains, thus, limiting surfaces occupied by dry Mediterranean ecosystems, and (3) the dense Abies/Fagus forest around the lake acted as a filter for regional rainfall.

Zones T-3b and T-3c (ca. 10 000-8900 cal BP) correspond to an optimum for Fagus and a regression for oak. Two sharp drops in the $\mathrm{AP}_{\mathrm{t}}$ rate which are centred at ca. 9800 and 9200 cal BP (Fig. 8) suggest Fagus forest openings. In T-4 (ca. 8900-7300 cal BP), terrestrial vegetation was stable before the $8200-7500$ cal BP interval which is marked by a regression of both Abies and Fagus. In zone T-5 (ca. 73006150 cal BP) Abies becomes more abundant than Fagus.

In zone T-6 (ca. 6150-5100 cal BP), the regression of Abies to the benefit of Fagus also suggests a dry episode. Zone T-7 (ca. 5100-4650 cal BP) is mainly characterised by an apparent reduction in mountain trees, but this is partly influenced by the auto-correlation between taxa percentages due to the high percent of aquatic plants and Osmunda. However, after stabilisation of Fagus and Abies in T-8, T-9 marks the beginning of forest regression at ca. $4000 \mathrm{cal}$ BP. This change is probably due to generalised forest opening by Bronze Age populations, though anthropogenic indicators are almost absent; a minor increase of Pteridium spores is nevertheless observed in this zone: known to take advantage of forest fires, this fern is an indicator of human disturbances.

Zone T-10 (ca. 3500-2100 cal BP) is characterised by a moderate Fagus/Abies forest restoration which remains unstable; frequent occurrences of Rumex, Chenopodiaceae and Plantago suggest pastoral activities in the woods.

The major event during zone T-11 (ca. 2100-800 cal BP) is the quasi-disappearance of Abies from the local forest, probably due to timber exploitation beginning in Roman times and/or to climate change. A positive correlation between Ostrya/Carpinus orientalis and Hedera helix $(r=0.52 ; p<0.001)$ is observed as these two taxa had developed and co-varied since $10500 \mathrm{cal}$ BP. In presentday Calabria, particularly in the Catena Costiera, Hedera helix is very common in the Ostrya wood communities where mesophyllous underwood development is favoured by high atmospheric moisture (Blasi et al., 2006). The quasidisappearance of Hedera, however, seems more concomitant with that of Abies and, therefore, underscores lower moisture or pastoral activities within the woods. In the upper part of T-11 also begins the continuous occurrences of Castanea and Juglans. Rare but regular Castanea pollen grains are identified throughout the Holocene. The early presence of chestnut reported in central and southern Italy (Lago di Lagdei, Bertoldi, 1980; Schneider, 1985; Mercuri et al., 2012) strengthens the hypothesis of an indigenous chestnut in these areas. Nowadays, it is intensively cultivated on the Monte Caloria slopes around Fagnano Castello where it has played an important economic role since medieval times, but it was apparently neglected by the Roman civilisation. On the contrary, there is no indication of the presence of Juglans before its early medieval introduction.

Zone T-12 (ca. 800-33 cal BP) is characterised by regional mixed-oak forest reduction and by anthropogenic indicators that are more frequent though not abundant. In Zone T-13, the collapse of Alnus and the increase of aquatic plants strongly influence pollen assemblages and prevent a reasonable reading of vegetation changes.

\subsubsection{Pollen sequence and hygrophilous vegetation}

From ca. 11500 to ca. 11000 cal BP (zones T-1 and T-2), hygrophilous taxa are represented by sparse aquatics indicating shallow water (Table 3). From 11000 to $8900 \mathrm{cal} \mathrm{BP}$ (T-3), abundant Botryococcus (colonies) are recorded, typical of an open lake with deep water (Testa et al., 2001) and gyttja sedimentation.

In zone T-4 (ca. 8900-7300 cal BP), open water receded to the benefit of a marginal swamp as illustrated by the abrupt reduction of the Botryococcus algal colonies and the expansion of marsh plants. Close attention to the abundant Asteroideae pollen grains shows them to belong to the genus Eupatorium; this plant still grows on the lake shore (Eupatorium cannabinum). The continuous curve of Osmunda confirms the infilling of the lake towards a pond as well as the sediment types, that records a change from gyttja to peat at ca. $8200 \mathrm{cal} \mathrm{BP}$, and is contemporaneous with Eupatorium expansion. In zone T-5 (7300-6150 cal BP) the marsh is invaded by Osmunda; the Cyperaceae curve shows a slight expansion of Carex paniculata which is still abundant on the site today.

In zone T-6 (ca. 6150-5100 cal BP), for the first time $A l$ nus invades the margins of the pond. The rise in the Alnus pollen curve occurs when the sediment is still a detritus gyttja, later replaced latter by a wooded peat guaranteeing that the tree was present at the coring point. This alder expansion may correspond to a terminal phase of lake infilling tending towards peatland, but the regression of Abies to the benefit of Fagus also suggests a dry episode. The deeper water recorded between ca. 5100 and $4650 \mathrm{cal} \mathrm{BP}$ (zone T-7) extinguished the Alnus fen to the benefit of Osmunda, Cyperaceae and Poaceae (which may correspond to Phragmites nowadays being well developed in the Lago dei Due Uomini; Fig. 2). During zone T-8 (ca. 4650-3950 cal BP), Alnus again invades the marsh, arriving at an optimum during zone T-9 (ca. 3950-3500 cal BP). Zone T-10 (ca. 3500$2100 \mathrm{cal} \mathrm{BP})$ corresponds to a new period of deep water 


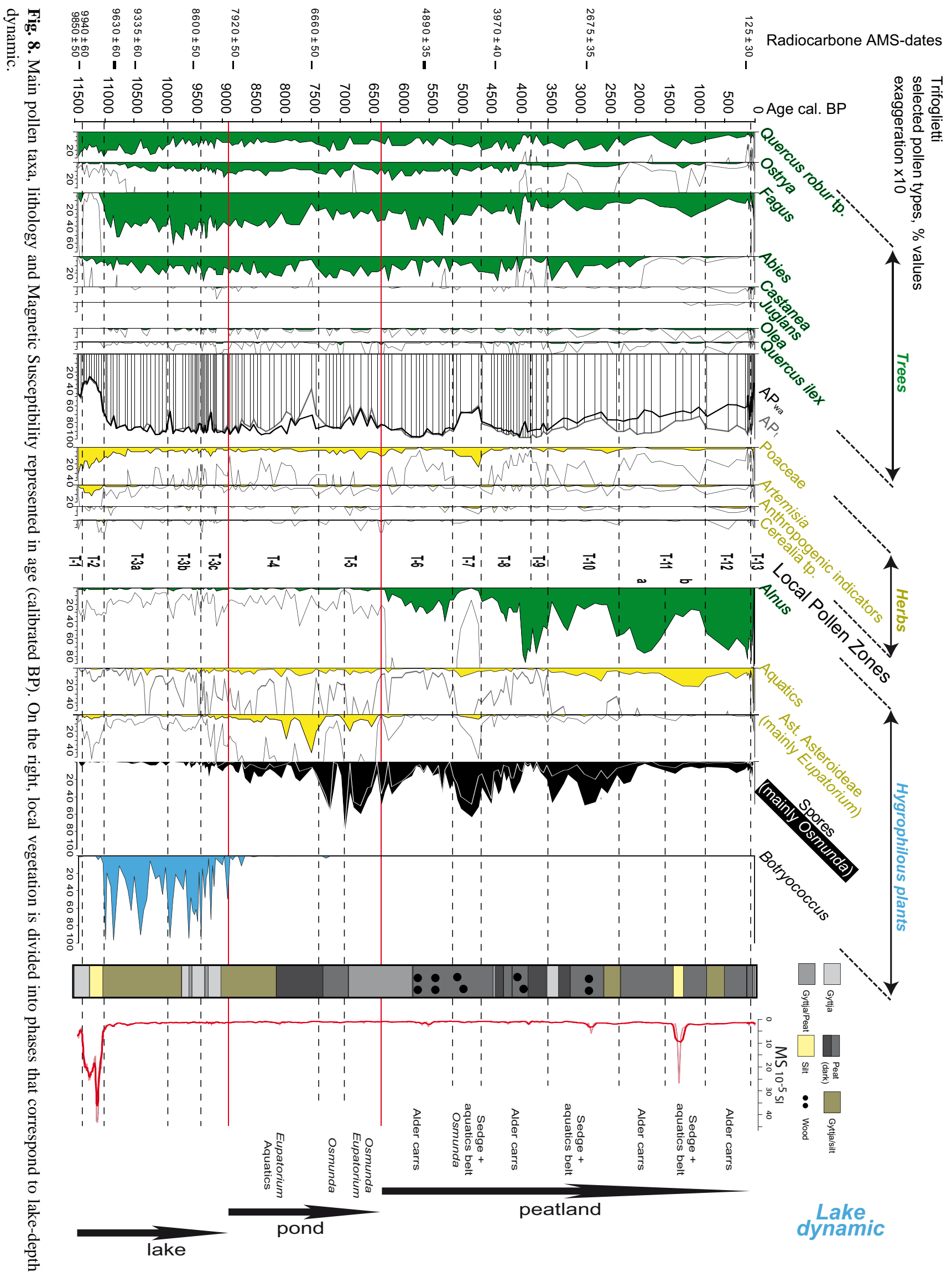


marked by alder decline to the benefit of aquatic plants and Osmunda. Within T-11 (ca. 2100-800 cal BP), two sub-zones can be distinguished T-11a (ca. 2300-1500 cal BP) and T-11b (ca. 1500-800 cal BP) (Fig. 8), the first characterised by a decrease in water depth with abundant Alnus, the second, by a return to sedges hummocks and deeper water. Zone T-12 (ca. 800-33 cal BP) is characterised by new alder expansion. This phase probably corresponds to a final episode in progressive lake infilling, abruptly stopped in zone T-13 reflecting the artificial present-day damming of the lake in order to maintain the hygrophilous ecosystem. The collapse of Alnus and increase of aquatic plants suggest that the objectives of recent anthropogenic lake restoration have been attained. According to Landi and Angliolini (2010), riparian alder-woods (Alnus glutinosa) and alder swamps have similar ecological characteristics and are associated to Osmunda regalis in Tuscany (Italy). Moreover, the Osmundo-Alnion phytocoenoses can be identified by their generally oligotrophic nature and presence in watercourses that do not dry up in summer, in contact with the water table or near springs. In the case of Lago Trifoglietti, this association is observed in the modern surface sample 1 (Fig. 6), however, when looking at the fossil record, abundant variations of Alnus and Osmunda are opposed. This suggests slight differences in ecological requirements of these two taxa.

\subsubsection{Changes in water-depth}

Variations in the hygrophilous taxa shown by the Trifoglietti pollen record reflect fluctuations in water depth. These can be reconstructed using ratios between indicators of lake development and those characteristic of peatland. This hygrophilous group was mainly composed of algae, fern spores (Osmunda and monoletes) and Alnus. First order clustering obtained from CONISS analysis clearly separates samples where algae (Botryococcus) and more terrestrial taxa (spores and Alnus) are dominant (Fig. 7). Thus, a first ratio can be proposed: (Botryococcus +1$) /($ Alnus + spores +1$)$. A second ratio of $($ Alnus +1$) /($ spores +1$)$ is established to synthesise the opposition between Alnus and spores. In those mathematic ratios, the value 1 is used so as to avoid values nullification. Finally, a ratio which combining the two previously defined ratios, is generated in order to infer environmental evolution; this uses a logarithmic representation illustrated in Fig. 9d.

The pollen-based water-depth curve shows relatively deep water conditions from ca. 11000 to $9000 \mathrm{cal} \mathrm{BP}$, intermediate water depth from ca. 9000 to ca. $6000 \mathrm{cal} \mathrm{BP}$, and shallower water from ca. $6000 \mathrm{cal} \mathrm{BP}$ to the present. This latest phase also gives evidence of second-order variations with shallower water episodes at ca. 6100-5200, 4650-3500 and 2400$1700 \mathrm{cal} \mathrm{BP}$, and deeper water episodes at ca. 5100-4650, 3500-2500 and after 1700 cal BP. Such a general decreasing trend since ca. $11000 \mathrm{calBP}$ (Fig. 9d) is consistent with the lithological change from silty-gyttja to peat sediments that may reflect natural lake infilling with detritic particles and organic matter. The progressive overgrowth of the lake favoured the development of alder carr. However, both long- and short-term changes in water-depth may also reflect climate-induced paleohydrological changes (more particularly during summer) as evidenced in central Italy and in Sicily (Ariztegui et al., 2000; Sadori et al., 2004; Giraudi et al., 2011; Magny et al., 2007a, 2011a,b).

\subsubsection{Pollen-based quantitative reconstruction of precipitation}

The quality of the MAT reconstruction appears acceptable for all the Holocene: the adopted threshold is 61.99, and only 2 samples between ca. 7950 and ca. $7500 \mathrm{yr}$ cal BP have been removed because the number of analogues selected was too low. For all other samples, 8 modern analogues have been selected for the climate reconstruction. The modern analogs selected are located in Italy (samples close to Lago Trifoglietti), Alps, and Pyrenean areas, except for the period between ca. 11500 to ca. $11200 \mathrm{cal} \mathrm{BP}$. This strong precipitation anomaly is driven by a switch from regional to extraregional analogues, from Italy to high-elevation East regions (Greece, Turkey). The dissimilarity coefficients are, however, acceptable in this part of the reconstruction, as for the entire sequence.

To test the MAT results and to obtain a more reliable climate reconstruction, results provided by the WAPLS have been added. These results are in accordance with the annual precipitation based on the MAT. Annual precipitations reconstructed at Trifoglietti are around $900-1000 \mathrm{~mm}(1100 \mathrm{~mm}$ for the first part of the Holocene, when Fagus percentages are particularly high) and the error bar is close to $1200 \mathrm{~mm}$ (it can reach $1800 \mathrm{~mm}$, not shown in the Fig. 9 for clarity). The quality of the reconstruction is acceptable, but the precipitations can appear underestimated taking into account the extremely high modern values $(1850 \mathrm{~mm})$. This underestimation may be related to the fact that this station is located at lower altitude (516 $\mathrm{m}$ a.s.1.) and is facing east (while Trifoglietti is facing west). Despite these uncertainties, when the climatic parameters - temperature or precipitation - are very low or high, all the methods often fail to reproduce such pattern (Combourieu Nebout et al., 2009). Therefore, it is preferable to discuss in terms of trend instead of raw values. The climate trend reconstructed at Lago Trifoglietti during the Holocene is consistent with closest sites such as Lake Preola in Sicily (see Peyron et al., 2012) and with the estimates obtained for a marine core located in the Gulf of Salerno (Fig. 9c) by Di Donato et al. (2008). These curves also seem in agreement with the fact that at present the natural populations of Mediterranean Abies live in areas where mean annual precipitations are above $1000 \mathrm{~mm}$.

From ca. 11500 to ca. 11200 cal BP (Fig. 9f, see also Peyron et al., 2012), MAT annual precipitation reconstructed at Trifoglietti illustrates a marked drying phase $\left(500 \mathrm{~mm} \mathrm{yr}^{-1}\right)$. 
The abrupt Fagus re-development at ca. $11200 \mathrm{cal}$ BP suggests a rapid increase in annual rainfall $(\Delta 200 \mathrm{~mm})$. This increase then continued progressively from ca. 10700 to ca. $8700 \mathrm{cal} B \mathrm{BP}(\triangle 250 \mathrm{~mm})$ which favoured Abies expansion. WAPLS Pann show similar variations and trends although range of values appears smoothed compared with MAT Pann $(\Delta 300 \mathrm{~mm}$ between ca. 11200 and ca. 8700 cal BP).

Both precipitation reconstruction show a long-term progressive drying from ca. 9500 to 1700 cal BP. Contrary to local hygrophilous vegetation dynamics which can be influenced by the lake-basin infilling, the climate reconstruction is quantified on the basis of terrestrial vegetation and, therefore, supports the Holocene drying trend observed in southern Italy and Sicily (Magny et al., 2007a, 2011a,b). Pluri-secular variations also appear to be superimposed on this millennial-scale trend such as a relatively humid period during the mid-Holocene climate optimum (ca. 9500 to $6000 \mathrm{cal}$ BP), drying phases (with low Abies values) at around $11300 \mathrm{cal} \mathrm{BP}$, ca. 8200-7500 cal BP, and a marked drying around $4200 \mathrm{cal} \mathrm{BP}$.

Since $1700 \mathrm{cal} \mathrm{BP}$, and despite Abies disappearance as well as oak regression and $\mathrm{AP}_{\mathrm{wa}}$ decrease, Fagus forest again attains the prevalence attested at the early Holocene and probably explains the final increase in the MAT Pann $(\Delta 300 \mathrm{~mm})$. However, this increase is not corroborated by WAPLS Pann and did not prevent the terminal colonisation of alder as the lake was finally overgrown.

\section{Discussion}

\subsection{Millennial-scale environmental and climatic trends}

During the last decade several pollen studies have shed new light on southern Italy's vegetation history (e.g., Lago Battaglia, Caroli and Caldara, 2007; Lago Alimini Piccolo, Di Rita and Magri, 2009; Lago Grande di Monticchio, Allen et al., 2002; Lago di Pergusa, Sadori et al., 2008; Tavoliere Plain, Di Rita et al., 2011; Fig. 1), though most of these concern lowlands. Lago Trifoglietti, however, appears as a unique example of a well-dated pollen sequence from the mountain belt of southern Italy.

On a millennial scale, given the relatively late and weak human impact observed in the Trifoglietti pollen record, changes in the vegetation as well as in the water-depth and annual precipitation may help to recognise long-term climate variations which have affected southern Italy since the early Holocene.

\subsubsection{Early Holocene expansion of mesophyllous forests in southern Italy}

The Trifoglietti pollen record with NAP values near $60 \%$ (see above, Sect. 4.2.2) suggests that the site was above the timberline at the beginning of the Holocene. At Monticchio (ca. $656 \mathrm{~m}$ a.s.1.), an abrupt expansion of the mesophillous forests is recorded for the beginning of the lateglacial interstadial (LGI) (Watts et al., 1996, Allen et al., 2002). There, deciduous oaks reach at an optimum (with abundant Tilia and Fagus continuous pollen curves) just before the Younger Dryas (zone 2). Thus, it may be that, on the Catena Costiera Mountains around Lago Trifoglietti, the timberline reached at least the same altitude. Nevertheless, the status above the timberline of Trifoglietti is surprising if we compare this site with those of the northern Apennines such as Prato Spilla A (1550 $\mathrm{m}$ a.s.1.) or Lago Padule (1187 m a.s.l.) (Lowe and Watson, 1993; Watson, 1996; Fig. 1) where Pinus and Abies are quite abundant during the LGI and where the very beginning of the Holocene is marked by expansion of deciduous forests and persistence of fir in the mountains. At Padule, AP percentages above $80 \%$ indicate that the site was below the timberline. How does one, thus, explain a lower earlyHolocene timberline at Trifoglietti in spite of lower latitude? In Sicily, at Lago di Pergusa (667 m a.s.l., Sadori and Narcisi, 2001; Sadori et al., 2011), oak expansion occurs progressively during the early Holocene (with abrupt development at ca. 9800 cal BP, Fig. 9h), along with low pollen-inferred precipitation (Magny et al., 2011a). In the littoral sites of Sicily, such as Preola and Gorgo Basso (Tinner et al., 2009; Magny et al., 2011b; Calò et al., 2012) or Biviere di Gela (Noti et al., 2009), open Mediterranean sclerophyllous shrubs were dominant and low lake-levels are recorded for the first part of the Holocene (Fig. 9g). All these observations suggest an increasing delay from northern to southern Italy where arid conditions persisted during a large part of the early Holocene (Magny et al., 2011b). These relatively dry conditions in the early Holocene may also have affected Calabria and may explain both a low-altitude timberline and a later expansion of Fagus at Trifoglietti.

\subsubsection{A preboreal oscillation cold event?}

The closest available pollen record of the lower-altitude Monticchio (656 m a.s.1.), shows that the forests did not retract much during the Younger Dryas which was marked by a succession of little oscillations in the AP curve (Allen et al., 2002). Thus, we initially believed that the major cooling observed in zone T-2 of the Trifoglietti pollen record may have been contemporary with the Younger Dryas cold event. Yet three consistent ${ }^{14} \mathrm{C}$ dates obtained at levels 843 and $806 \mathrm{~cm}$ suggest to correlate it with the Preboreal oscillation (PBO; Björck et al., 1997) and Bond event 8 (Bond et al., 2001). Consequently, our zone T-2 may be contemporary with a short and late increase in NAP (mostly Poaceae), dated between $11500-11300 \mathrm{cal} \mathrm{BP}$, at the end of zone 2 in the Monticchio sequence (Fig. 9b; Allen et al., 2002); this is supported by the fact that, at the two sites, this cooling is immediately followed by beech expansion. The PBO is sometimes considered as difficult to identify from Mediterranean paleoenvironmental records (Fletcher et al., 2010; Di Rita et al., 


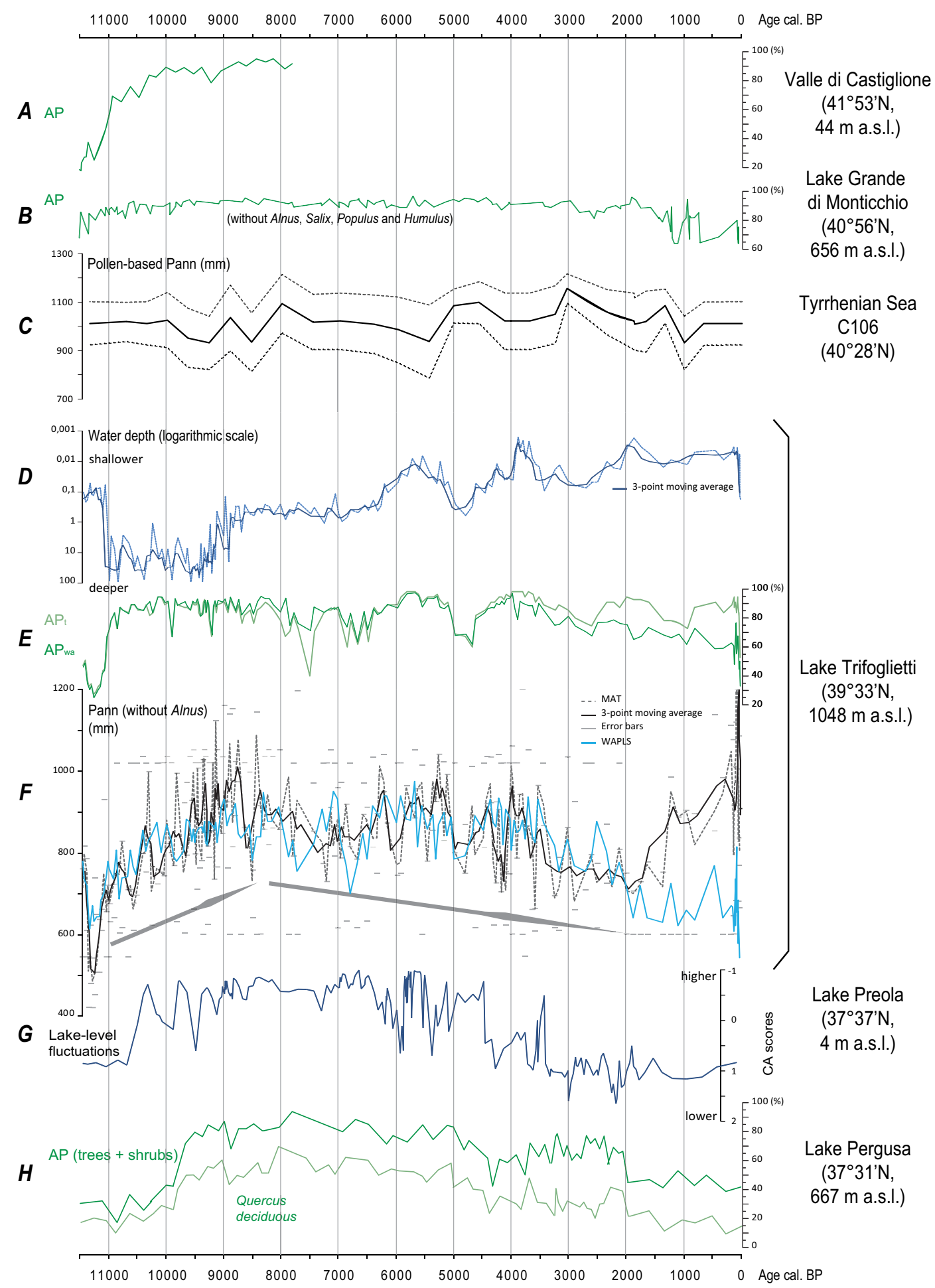

Fig. 9. Comparison of paleorecords from Valle di Castiglione (A; Di Rita et al., 2012), Lake Grande di Monticchio (B; AP changes; Allen et al., 2002), C106 marine core [C; pollen-based annual precipitation (Pann); Di Donato et al., 2008], Lago Trifoglietti [D, pollen-based water-depth; E, $\mathrm{AP}_{\mathrm{t}}$ and $\mathrm{AP}_{\mathrm{wa}}$ (Arboreal Pollen total or Without Alnus); F, pollen-based annual precipitation (Pann) using MAT and WAPLS methods], Lake Preola (G; lake-level changes; Sicily, Magny et al., 2011b) and Lake Pergusa (H; AP changes and deciduous Quercus; Sicily, Sadori et al., 2011). 
2012). At Lake Accesa in central Italy, the climate conditions prevailing during the $\mathrm{PBO}$ around 11300 to $11150 \mathrm{cal} \mathrm{BP}$ are characterised by increased Artemisia and by low lake level (Magny et al., 2007a; Finsinger et al., 2010). Further south, a PBO has recently been reported in Valle di Castiglione where it corresponded to a decrease in AP at ca. 11450$11200 \mathrm{cal} \mathrm{BP}$ and to dry climate conditions (Fig. 9a; DiRita et al., 2012). At Trifoglietti, the return of an open vegetation landscape (probably situated above the timberline) is synchronous with the deposition of a silt layer in the lake basin. Furthermore, pollen-inferred annual precipitation is marked by a minimum while the reconstructed water depth (Fig. 9d) shows a dry interval. Thus, a growing body of records support the past occurrence of a dry PBO in central and southern Italy (Magny et al., 2007b). Nevertheless, the magnitude of the PBO observed at Trifoglietti, in terms of both NAP increase (and associated timberline decline) and water-table lowering, may appear to be excessive in comparison with other regional records. Further investigations at Trifoglietti and elsewhere in the southern Italy will be needed to replicate the data presented above, so as to control the chronology of the Trifoglietti record by additional radiocarbon dates and to check whether or not the marked palaeoenvironmental changes observed at Trifoglietti were simply a strong response to the PBO due to local particularities.

\subsubsection{The early Holocene (ca. 11 000-9000 cal BP)}

Regarding the vegetation history for the period following the $\mathrm{PBO}$, pollen records from mountainous zones remain scarce in southern Italy. As noted above, one can mention lakes Zapano (1420 m a.s.1.) and Remmo (1525 m a.s.1.) in Monte Sirino, studied by Chiarugi (1937) and by Reille (19921998) in the seventies (communication of unpublished data) showing dominant beech forests during the late Holocene. In Calabria also, at Canolo Nuovo (900 m a.s.l.) a simplified diagram by Schneider (1985) suggests a landscape shared between oak and beech forests throughout the Holocene. The interval corresponding to zone T-3 (major phase of beech expansion, between ca. 11000 and $8900 \mathrm{cal} \mathrm{BP}$ ) is marked at Monticchio and Pergusa by a moderate maximum of Corylus which is weakly expressed in the Trifoglietti pollen record. This suggests that Corylus and its associated mesophyllous mixed-oak forest were not able to penetrate the fir/beech belt. At Monticchio, Ostrya/Carpinus orientalis is present during the LGI, but begins to expand at ca. $10500 \mathrm{cal} \mathrm{BP}$, i.e., at the same time as at Trifoglietti. It was favoured by increasing annual precipitation at Trifoglietti and synchronous with higher lake level at Preola in Sicily (Magny et al., 2011b). Sclerophyllous taxa (Olea, Quercus ilex type) are very scarce as their pollen transportation by ascending winds was probably insufficient here. This is also the case for Pistacia, abundant in the coastal sites of Sicily (Noti et al., 2009; Tinner et al., 2009), but extremely rare in the Trifoglietti record.

\subsubsection{The mid-Holocene climate optimum (9000-6000 cal BP)}

Annual precipitation reconstructed at Trifoglietti is high from ca. 9500 to $6000 \mathrm{cal} \mathrm{BP}$ and attain its maximum at ca. $8700 \mathrm{cal} \mathrm{BP}$. The wettest conditions are reported throughout the central Mediterranean region (e.g., Ariztegui et al., 2000; Sadori and Narcisi, 2001; Drescher-Schneider et al., 2007; Frisia et al., 2006; Zanchetta et al., 2007; Sadori et al., 2008; Leng et al., 2010; Colonese et al., 2010; Finsinger et al., 2010) and are contemporary with enhanced rainfalls over the northern borderlands during the deposition of sapropel (organic-carbon-rich sediments) S1 in the Adriatic Sea (Siani et al., 2010) and in the central-eastern Mediterranean Basin (e.g., Ariztegui et al., 2000).

In this case, despite the natural lake-infilling dynamic at Trifoglietti, the pollen-based water-depth record suggests deep water in the context of increasing annual precipitation up to $8800 \mathrm{cal} \mathrm{BP}$. This is broadly consistent with changes in the clay mineral assemblage from the Gulf of Salerno (core C106 in the Tyrrhenian Sea; Fig. 1), which indicate increasing precipitation in the source area, but at longer time intervals (i.e., 9500 to $6000 \mathrm{cal} \mathrm{BP}$; Naimo et al., 2005). It is also consistent with lower salinity reconstructed from $\delta^{18} \mathrm{O}$ record in the marine core MD90-917 (Siani et al., 2012) and is in accordance with snail shell composition recorded from the Latronico 3 cave in southern Italy (Fig. 1). There, decreasing measured $\delta^{18} \mathrm{O}$ values are associated with enhanced rainfall and lower evaporation rates, possibly triggered by increases in westerly activity (Colonese et al., 2010).

From the Mid- to the Late Holocene, water depth as well as annual precipitation show a general decrease at Trifoglietti. This is consistent with a fall in lake level observed in Sicily (Fig. 9g; Magny et al., 2011b) while a contrasting paleohydrological pattern has been reconstructed for central Italy (Magny et al., 2007a). Thus, the water-depth decrease since $9500 \mathrm{cal} \mathrm{BP}$ at Trifoglietti may have resulted from the combined effects of lake-basin infilling and a generally drier climate in the south-central Mediterranean. Considering its intermediate location between palaeohydrological records from central Italy and Sicily, the water-depth record of Lago Trifoglietti (Fig. 9d) supports the working hypothesis discussed by Magny et al. (2011a) of contrasting patterns in precipitation seasonality north and south of latitude $40^{\circ} \mathrm{N}$ in the central Mediterranean in response to orbitally-induced climate changes.

\subsubsection{Towards the late Holocene (from ca. 6000 cal BP to the present)}

Since ca. 6000 cal BP, Trifoglietti has become a peatland (Fig. 8) with shallow water (Fig. 9d), probably due to the persisting and joint effects of drier climate and lakebasin infilling. Schneider (1985) also reported hydrological change (perhaps associated with temperature change) in the 
Canolo Nuovo site (945 m a.s.1.; Fig. 1) reflected by a Quercus ilex expansion and a fen development with Alnus, Osmunda regalis and Sparganium around 5000 uncal BP (i.e., ca. 5800 cal BP). In the Tyrrhenian Sea, the typical presentday foraminiferal association recognised in the core BS7922 testifies to the onset of deep winter water convection and vertical mixing starting at $6 \mathrm{ka}$ which characterise the modern Tyrrhenian Sea (Fig. 1; Sbaffi et al., 2001). Since this date, the long-term salinity trend in the Adriatic Sea has been stable, despite higher frequency changes (Siani et al., 2012). It may, therefore, suggest that stabilised marine circulation around the southern Italian peninsula coeval with inland stable hydrological pattern in southern Italy. It has been related to effects of Neoglaciation in the Mediterranean, North Atlantic and Arctic areas since ca. 5700 cal BP (Marchal et al., 2002; Miller et al., 2010; Giraudi et al., 2011).

\subsection{Centennial-scale environmental and climatic changes}

The data collected at Trifoglietti also illustrate highfrequency climate variability during the Holocene in the southern Italy.

\subsubsection{Early and mid Holocene}

Two sharp drops in AP centred at ca. 9800 and 9200 cal BP (Fig. 9e) correspond to beech forest openings and increases in aquatic taxa, coincided with decreases in Pann (Fig. 9f). Taking into account radiocarbon-age uncertainty, these events may be related to the well-known cold Boreal oscillations recognised at higher latitudes (Magny et al., 2001; Rasmussen et al., 2007; Fleitmann et al., 2007; $\mathrm{Yu}$ et al., 2010; Fletcher et al., 2010). In other terrestrial archives, an AP decrease is recorded at Monticchio at ca. 9800 cal BP, while at Valle di Castiglione the AP record shows lower values at ca. 9300-9200 cal BP (Di Rita et al., 2012; Fig. 9a). In the Tyrrhenian Sea, core BS7938 (Fig. 1) gives evidence of two peaks in cold foraminiferal species (particularly Neogloboquadrina pachyderma, right coiling) at ca. 9800 and $9000 \mathrm{cal} \mathrm{BP}$ (Sbaffi et al., 2004).

From ca. 8200 to $7500 \mathrm{cal} \mathrm{BP}$, an $\mathrm{AP}_{\mathrm{wa}}$ reduction marks changes in climate conditions at Trifoglietti (Fig. 9e). More arid conditions recorded in Pann ( $\Delta 150 \mathrm{~mm}$, Fig. 9f) and reduced fir and beech woods favoured the expansion of marsh plants and the deposition of dark peat characteristic of shallower water. Around $8200 \mathrm{cal} \mathrm{BP}$, a general cooling associated with the $8.2 \mathrm{kyr}$ event was recorded in the Mediterranean region (e.g., Bordon et al., 2009; Pross et al., 2009; Fletcher et al., 2010; Sadori et al., 2011). As observed in the eastern Mediterranean (Dormoy et al., 2009), this $8.2 \mathrm{kyr}$ event is also associated with dryer climate conditions, but spans only ca. $200 \mathrm{yr}$ (Pross et al., 2009). Therefore, no vegetation change spanning several centuries has been observed in other pollen records (e.g., Sadori and Narcisi, 2001;
Allen et al., 2002). At Lake Preola, Magny et al. (2011b) observed a moisture decrease phase from 8300 to 6900 in the central core LPBC and two phases at 8400-8200 and 7400 cal BP in the littoral core LPA, which may be compared with the two successive cool and dry events recorded at ca. 8200 and $7500 \mathrm{cal} \mathrm{BP}$ in carbone- and oxygen-isotope records from speleothems in northern Sicily (Frisia et al., 2006). As discussed by Rohling et al. (2002), the interruption of Sapropel 1 during the $8.2 \mathrm{kyr}$ event (Ariztegui et al., 2000) probably corresponded to a strengthening of the winter Siberian High responsible for cooler and drier climatic conditions with more frequent polar/continental outbreaks over the eastern Mediterranean. Around the Italian Peninsula, marine sequences from the Adriatic and Tyrrhenian Seas also reveal a bi-phased Sapropel 1 interrupted at ca. 8200 cal BP (Siani et al., 2010) or from ca. 8000 to $7500 \mathrm{cal} \mathrm{BP} \mathrm{(Ariztegui}$ et al., 2000), marked by changes in faunal, organic and isotopic contents. According to Siani et al. (2010, 2012), short-term SST cooling spell recoded in MD90-917 core is responsible for the resumption of deep-water formation and re-oxygenation phases in the South Adriatic basin at $8.2 \mathrm{ka}$ during the $\mathrm{S} 1$ interruption. According to Sangiorgi et al. (2003), surface waters in the Adriatic Sea (as reflected by core AD91-17; Fig. 1) were relatively unaffected by lowered temperatures, but winter winds were responsible for the sapropel interruption and associated water mixing and reoxygenation. On the basis of SST records from core BS7938 in the Tyrrhenian Sea, Sbaffi et al. (2004) reported a short cooling episode (labeled SCE5 event) of about $2-2.5^{\circ} \mathrm{C}$ from ca. 8200 to $7500 \mathrm{cal} \mathrm{BP}$. Ariztegui et al. (2000), using terrestrial (i.e., Lakes Albano and Nemi in central Italy; Fig. 1) and marine data (i.e., core MC82-12 in the Tyrrhenian Sea) came to the conclusion that both continental and marine realms underwent a reduction in precipitation and/or fluvial inflow from ca. 8200 to $7500 \mathrm{cal}$ BP. During this time, the impact of more frequent outbreaks of Siberian dry winter air masses in the eastern Mediterranean may have extended toward south Italian Peninsula. In MD90-917, the SSTs drop of about $3{ }^{\circ} \mathrm{C}$ during the cold $8.2 \mathrm{ka}$ event, is followed by a short-lived centennial lighter cooling $\left(1^{\circ} \mathrm{C}\right)$ between 7.8 and $7.5 \mathrm{ka}$ at the time of sapropel S1b (Siani et al., 2012). It can, therefore, suggest that several short events added and/or mixed during the time interval 8200-7500 cal BP due to low temporal resolution and chronological uncertainties.

From ca. 7000 to ca. $6400 \mathrm{cal} \mathrm{BP}$, the $\mathrm{AP}_{\mathrm{wa}}$ and WAPLS Pann records show a decrease. In Basilicata, Piccarreta et al. (2011) observed an increase in flood frequency from ca. 7200 to $6300 \mathrm{calBP}$ (the strongest phase is up to ca. $6800 \mathrm{cal} \mathrm{BP}$ ) which is related to colder and moister climate. This correlates with indication of SST cooling inferred from foraminiferal assemblages in core AD91-17 (Sangiorgi et al., 2003) and MD90-917 (Siani et al., 2012) in the Adriatic Sea. At Trifoglietti, this decline of AP could reflect a locally more developed human impact as shown by slight increases in anthropogenic indicators and Cerealia (Fig. 8). 
At Santuario della Madonna Cave, periods of human activity are interspersed in deposits which characterised the record of rapid oscillations in the moisture regime during the Late Neolithic (since 5th millennia BC; Scarciglia et al., 2009). However, this hypothesis needs to be tested by further investigation in a region (Calabria) marked by the scarcity of archeological findings and more particularly in the mountainous areas.

\subsubsection{Mid- and late Holocene}

Near the final stage of the full overgrowth of the lakebasin, the Trifoglietti site becomes more sensitive to shortterm minor variations in humidity. Thus, superimposed over the general trend towards shallow water, three successive phases of shallower water are identified (ca. 6100-5200, ca. 4300-3500 and ca. 2500-1800 cal BP), and three phases of deeper water (ca. 5200-4300, ca. 3500-2500 and after ca. 1800 cal BP).

From ca. 6100 to ca. 5200 cal BP, the first shallow water phase corresponds to alder expansion reflecting evolution towards the terminal phase of lake infilling, but the regression of fir to the benefit of beech also suggests a dry episode, this corresponds to a ca. $100 \mathrm{~mm}$ summer precipitation decrease inferred by quantitative climate reconstruction (Peyron et al., 2012). Alder development is also reported at Canolo Nuovo at ca. 5000 uncal BP (i.e., ca. 5800 cal BP; Schneider, 1985). This time interval is also characterised by a cooling associated with the short cold event (SCE4) reported in marine cores from the Tyrrhenian (annual SST; BS7937; Sbaffi et al., 2004) and Adriatic Seas (alkenone SST; AD9117; Sangiorgi et al., 2003). Magny (2004) and Magny et al. (2012) have already discussed the possible impact in Europe of a cold event related with a Rapid Climate Change (RCC) between 6000 and $5000 \mathrm{cal} \mathrm{BP}$ defined by Mayewski et al. (2004). Local effect of these RCC may, thus, have affected the rain regime in the Alps where successive episodes of higher lake level between 5550 and $5300 \mathrm{cal} \mathrm{yr} \mathrm{BP}$ are observed at Lake Constance, coinciding with glacier advance (Magny and Haas, 2004). The wet and cool climate oscillation (wet winter but dry summer) observed in southern Italy contrasts with higher lake levels reconstructed in central and northern Italy (Magny et al., 2007a, 2012), and is in accordance with wet and cool conditions from 6000 to $5400 \mathrm{cal} \mathrm{BP}$ reported in the eastern Mediterranean by Finné et al. (2011).

From ca. 5200 to $4300 \mathrm{cal} \mathrm{BP}$, a more humid phase is inferred from deeper water reconstructed at Trifoglietti. This is supported by increases in annual precipitation (Fig. 9c, C106, Di Donato et al., 2008) and summer precipitation (Peyron et al., 2012). This phase also coincides with a reduction in forest cover at Trifoglietti, which can also be affected by a bias in $\mathrm{AP}_{\text {wa }}$ percentages.

A shallow water phase is recorded from ca. 4300 to ca. 3500 cal BP. It suggests drier summer climate conditions that may be equivalent to a fall in lake-level dated to $4500-4000 \mathrm{cal}$ BP in Lake Preola (Sicily; Magny et al., 2011b), while an abrupt rise in lake level is observed in central and northern Italy (Magny et al., 2007a, 2012). According to Magny et al. (2011a), the orbitally-induced reorganisation of atmospheric circulation led to a southward migration of westerlies bringing more humidity to latitudes higher than $40^{\circ} \mathrm{N}$, whereas opposite drier conditions developed in the south-central Mediterranean. At Trifoglietti, this dry episode was particularly accentuated from 4000 to $3600 \mathrm{cal} \mathrm{BP}$ if we consider the water-depth record (Fig. 9d), and around 4200 cal BP if we refer to the MAT Pann record (Fig. 9f). Such dry climate oscillation around 4400-4000 cal BP has been recognised from previous studies in the central and eastern Mediterranean (Drysdale et al., 2006; Di Rita and Magri, 2009; Noti et al., 2009; Tinner et al., 2009; Finné et al., 2011; Roberts et al., 2011b). At higher latitudes, it coincided with the beginning of the Neoglacial (Giraudi et al., 2011; Zanchetta et al., 2012; Vannière et al., 2012), marked by a glacier readvance in the Gran Sasso massif in central Italy.

From ca. 3500 to ca. 2600 cal BP, a phase of deeper water is associated with a reduction in alder carr. This more humid phase favours beech/fir forest restoration (despite relative instability) and corresponds to peaks in annual precipitation (Fig. 9f; Peyron et al., 2012). The drop in $\mathrm{AP}_{\mathrm{wa}}$ is linked to frequent occurrences of Rumex, Chenopodiaceae and Plantago which suggest pastoral activities in the surrounding forests. The $3500-2600 \mathrm{cal} \mathrm{BP}$ time interval coincided with decreasing temperature at Monticchio (MTCO; Allen et al., 2002) as well as with increasing precipitation as inferred from the pollen record of the marine core $\mathrm{C} 106$ (Fig. 9C; Di Donato et al., 2008). From core BS7938 in the Tyrrhenian Sea, Sbaffi et al. (2004) reported a cooling in annual SST (by ca. $2.5-3.5^{\circ} \mathrm{C}$ ) and suggested it may be equivalent to a short cooling episode (event SCE2). The alkenone SST record from core AD91-17 (Sangiorgi et al., 2003) also suggests cooler conditions in the Adriatic Sea. This cool oscillation is also recorded in the Aegean Sea where changes in the foraminifera species document polar air outbreaks over the north-eastern Mediterranean (Rohling et al., 2002).

Taking into account radiocarbon-age uncertainty, the drying phase observed at Trifoglietti around 2500-1800 cal BP from both water-depth and annual precipitation records (Fig. 9d and f) may be an equivalent to the well-known cooling phase identified around $2700-2500 \mathrm{cal} \mathrm{BP}$ at the Subboreal-Sublatlantic transition (van Geel et al., 2000), well marked by glacier advances in the Alps (Deline and Orombelli, 2005; Ivy-Ochs et al., 2009). The drier conditions recognised at Trifoglietti contrast with the phase of higher lake levels observed at higher latitudes in central and northern Italy (Magny et al., 2007a, 2012).

After ca. $1800 \mathrm{cal}$ BP, the Trifoglietti water-depth record (Fig. 9d) appears to be relatively stable, probably due to the nearly complete overgrowth of the lake basin making it less sensitive to further variation in humidity which might have 
been associated with more recent climate oscillations such as the Little Ice Age.

\subsection{Human impact history}

Archaeological studies in Calabria have revealed a great number of Neolithic villages along the coast (e.g., Santuario della Madonna Cave, 40-70 m a.s.l., Scarciglia et al., 2009), but at Trifoglietti anthropogenic indicators are absent or ambiguous for that time interval. Local mountain forests may have filtered the signalling of regional disturbances, but surprisingly oak and Ostrya pollen signals from altitudinal zones favourable to Neolithic agriculture do not show pertinent changes. This suggests that the surfaces submitted to slash and burn activity, were probably too small to modify regional pollen influx at Trifoglietti, and/or that the steep slopes between the site and the sea were unfavourable to settlement. Therefore, the palaeoenvironmental record established at Trifoglietti appears to show only weak effects of human impact and it may offer useful information about general climatic conditions prevailing during the Neolithic expansion in southern Italy. Berger and Guilaine (2009) raised the question of a possible relation between the $8.2 \mathrm{kyr}$ event and a delay in the Neolithic expansion in the Mediterranean basin. The first Neolithic settlement in south-western Italy was recognised at the Grotta di Latronico (Fig. 1) and dated to ca. 7700-7500 cal BP (Colonese et al., 2010), i.e., during a phase characterised at Trifoglietti by drier climate conditions (Fig. 9). However, further investigations and more radiocarbon dates are needed in order to better constrain the chronology of both Neolithic expansion and Holocene climate changes in southern Italy, and for a better understanding of possible relationships between climatic and cultural changes.

Since ca. $4000 \mathrm{cal} \mathrm{BP}, \mathrm{AP}_{\mathrm{wa}}$ has steadily recorded forest reduction that can be related to the combined effects of (1) the mid- to late Holocene climate drying and (2) the increasing impact of growing populations. Clear disturbances in forest ecosystems are observed (drop in pollen percentages of Abies and Fagus, but also of deciduous oaks). However, the forest reduction probably concerned mostly the collinean (oak decrease) and Mediterranean belts (sclerophylous taxa development). Broadly synchronous deforestation has been indicated in several pollen sequences from southern Italy and interpreted by Di Rita and Magri (2009) as an aridity crisis combined with progressive increasing human impact. At Trifoglietti, this is marked by (1) during the middle Bronze age, the use of fire to clear land for agricultures and grazing (Pteridium spores) and (2) since the Middle Ages, the cultivation of Castanea, Juglans and Olea. The exploitation of Abies for timber in Roman times is expected to caused the disappearance of Abies, however, climate change (marked by a drought at ca. $2000 \mathrm{cal} \mathrm{BP}$ ) cannot be excluded (Allen et al., 2002).
Pollen-based vegetation poorly records cereals, which can be wild cereal growing in southern Apeninnes (Schneider, 1985), and also of anthopogenic indicators with the exception of those indicating pastoral activities in forests. The distal signal of antropogenic impact remains extremely faint as shown by the still high $\mathrm{AP}_{\text {wa }}$ percentages, while beech forest remains dominant around the lake.

\section{Conclusions}

The high-resolution pollen-record of Lago Trifoglietti provides new insights into palaeoenvironmental and palaeoclimatic changes which may have characterised the Holocene period in southern Italy:

- The history of Holocene vegetation cover shows that an important and relatively stable forest, directly inherited from the early Holocene, was able to survive throughout that entire period in the form of a dense beech forest. This, therefore, constitutes a rare example of a beech woodstand which has survived climate changes for more than $11000 \mathrm{yr}$ and suggests that changes in temperature and precipitation in the growing season at Trifoglietti never attained a magnitude sufficient to alter the high competitivity of a thick beech forest.

- The pollen analysis supports a southward delay in the thermophyllous forest expansion dated to ca. 13500 cal BP at Monticchio, ca. 11000 cal BP at Trifoglietti, and finally ca. 9800 cal BP in Sicily. Persistence of arid conditions is expected to explain the increasing delay from northern to southern Italy.

- The pollen record of Trifoglietti shows only poor imprints of agricultural activity and anthopogenic indicators, apart from those indicating pastoral activities beneath forest cover. The strongest human impact in the Trifoglietti surroundings is the selective exploitation of fir.

- Using (1) a specific ratio between hygrophilous and terrestrial taxa, and (2) the Modern Analogue Technique, the pollen data collected at Lago Trifoglietti led to the establishment of two palaeoclimatic records based on changes in (1) lake depth and (2) annual precipitation. This allows recognition of both millennial-scale trends and centennial-scale oscillations which may have characterised the Holocene in the southern Italy. Thus, on a millennial scale, the records suggest increasing moisture from ca. 11000 to ca. $9400 \mathrm{cal} \mathrm{BP}$, a maximum of humidity from ca. 9400 to ca. $6200 \mathrm{cal} \mathrm{BP}$, before a general trend towards drier climate conditions that prevail up to the present. Superimposed on these millennialscale trends, several successive centennial-scale oscillations appear to have punctuated the entire Holocene as described below. Identification of a cold dry event 
around $11300 \mathrm{cal} \mathrm{BP}$, responsible for a marked decline in timberline altitude and possibly equivalent to the PBO, must be confirmed by further investigations to verify both chronology and magnitude. Two cold and possibly drier Boreal oscillations developed at ca. 9800 and $9200 \mathrm{cal} \mathrm{BP}$. The $8.2 \mathrm{kyr}$ event corresponded at Trifoglietti to the onset of cooler and drier climatic conditions which persisted until ca. 7500 cal BP. Finally, the second half of the Holocene was characterised by dry phases at ca. 6100-5200, 4400-3500, and 25001800 cal BP, alternating with more humid phases at ca. 5200-4400 and ca. 3500-2500 cal BP. Considered as a whole, these millennial-scale trends and centennialscale climatic oscillations support contrasting patterns of palaeohydrological changes recognised between the north- and south-central Mediterranean.

Acknowledgements. This study was supported by the French ANR (project LAMA, M. Magny and N. Combourieu Nebout). We thank G. Zanchetta, W. Fletcher, D. Magri, L. Sadori, one anonymous reviewer and M. F. Loutre (Editor) for thorough reviews and appreciable improvements of this manuscript. We are grateful to the authorities of the city of Fagnano Castello for their interest and we also thank J. Didier and A. Jacotot for their help in the field. We particularly appreciated the help of G. Escarguel in constructing the water-depth ratio and are also grateful to J. R. M. Allen and V. Di Donato who kindly provided the data from Lago Grande di Monticchio and the $\mathrm{C} 106$ core, respectively. The authors also express their sincere thanks to J. Olsen for his help with the English language.

\section{Edited by: M.-F. Loutre}

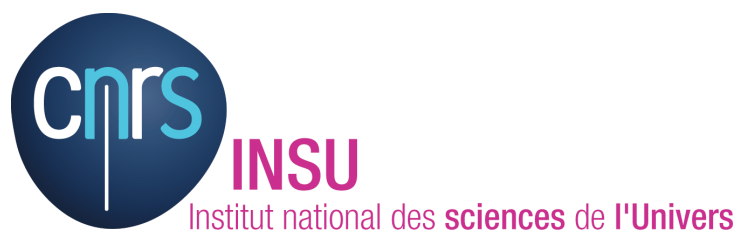

The publication of this article is financed by CNRS-INSU.

\section{References}

Allen, J. R. M., Watts, W. A., McGee, E., and Huntley, B.: Holocene environmental variability-the record from Lago Grande di Monticchio, Italy, Quatern. Int., 88, 69-80, 2002.

Ariztegui, D., Asioli, A., Lowe, J. J., Trincardi, F., Vigliotti, L., Tamburini, F., Chondrogianni, C., Accorsi, C. A., Bandini Mazzanti, M., Mercuri, A. M., van der Kaars, S., McKenzie, J. A., and Oldfield, F.: Palaeoclimate and the formation of sapropel S1: inferences from Late Quaternary lacustrine and marine sequences in the central Mediterranean region, Palaeogeogr. Palaeocl., 158, 215-240, 2000.

ARSSA: I suoli della Calabria. Carta dei suoli in scala 1:250.000 della Regione Calabria, 2003.
Asioli, A., Trincardi, F., Lowe, J. J., and Oldfield, F.: Short-term climate changes during the Last Glacial-Holocene transition: comparison between Mediterranean records and the GRIP event stratigraphy, J. Quaternary Sci., 14, 373-381, 1999.

Barthélémy, L. and Jolly, M. C.: Milieux de montagne et palynologie, Acta Biologica Montana, 9, 325-332, 1989.

Berger, J. and Guilaine, J.: The 8200 cal BP abrupt environmental change and the Neolithic transition: A Mediterranean perspective, Quatern. Int., 200, 31-49, 2009.

Bertoldi, R.: Le vicende vegetazionali e climache nella sequenza paleobotanica würmiana e post-würmiana di Lagdei (Appennino Settentrionale), in Ateneo Parmense, Acta Nat., 16, 147-175, 1980.

Beug, H. J.: Leitfaden der Pollenbestimmung für Mitteleuropa und angrenzende Gebeite, Pfeil, München, 2004.

Björck, S., Kromer, B., Johnsen, S., Bennike, O., Hammarlund, D., Lemdahl, G., Possnert, G., Rasmussen, T. L., Wohlfarth, B., Hammer, C. U., and Spurk, M.: Synchronized terrestrialatmospheric deglacial records around the North Atlantic, Science, 274, 1155-1160, 1996.

Björck, S., Rundgren, M., Ingólfsson, O., and Funder, S.: The Preboreal oscillation around the Nordic Seas: terrestrial and lacustrine responses, J. Quaternary Sci., 12, 455-465, 1997.

Björck, S., Walker, M. J. C., Cwynar, L. C., Johnsen, S., Knudsen, K.-L., Lowe, J. J., Wohlfarth, B., and Integration of Ice-core, Marine and Terrestrial Records (INTIMATE) Members: An event stratigraphy for the Last Termination in the North Atlantic region based on the Greenland ice-core record: a proposal by the INTIMATE group, J. Quaternary Sci., 13, 283-292, 1998.

Björck, S., Muscheler, R., Kromer, B., Andresen, C. S., Heinemeier, J., Johnsen, S. J., Conley, D., Koç, N., Spurk, M., and Veski, S.: High-resolution analyses of an early Holocene climate event may imply decreased solar forcing as an important climate trigger, Geology, 29, 1107-1110, 2001.

Blasi, C., Filibeck, G., and Rosati, L.: Classification of the Southern Italy Ostrya carpinifolia woods, Fitosociologia, 43, 3-23, 2006.

Bond, G., Kromer, B., Beer, J., Muscheler, R., Evans, M. N., Showers, W., Hoffmann, S., Lotti-Bond, R., Hajdas, I., and Bonani, G.: Persistent solar influence on north Atlantic climate during the Holocene, Science, 294, 2130-2136, 2001.

Bordon, A., Peyron, O., Lézine, A., Brewer, S., and Fouache, E.: Pollen-inferred Late-Glacial and Holocene climate in southern Balkans (Lake Maliq), Quatern. Int., 200, 19-30, 2009.

Brugiapaglia, E., de Beaulieu, J. L., Guiot, J., and Reille, M.: Modern pollen rain and the vegetation belt in the Taillefer Massif (Isere France), Geogr. Phys. Quatern., 52, 209-218, 1998.

Calò, C., Henne, P. D., Curry, B., Magny, M., Vescovi, E., Mantia, T. L., Pasta, S., Vannière, B., and Tinner, W.: Spatio-temporal patterns of Holocene environmental change in southern Sicily, Palaeogeogr. Palaeocl., 323-325, 110-122, 2012.

Caroli, I. and Caldara, M.: Vegetation history of Lago Battaglia (eastern Gargano coast, Apulia, Italy) during the middle-late Holocene, Veg. Hist. Archaeobot., 16, 317-327, 2007.

Chiarugi, A.: Prime Notozie sui cicli forestali postglaciali nell'Appenino Lucano, N. Giorn. Bot. Ital., 44, 624-627, 1937.

Ciancio, O.: Sul clima e sulla distribuzione altimetrica delle vegetazione forestale in Calabria, Ann. Ist. Sper. Selv., 2, 323-372, 1971. 
Colonese, A. C., Zanchetta, G., Dotsika, E., Drysdale, R. N., Fallick, A. E., Grifoni Cremonesi, R., and Manganelli, G.: Earlymiddle Holocene land snail shell stable isotope record from Grotta di Latronico 3 (southern Italy), J. Quaternary Sci., 25, 1347-1359, 2010.

Combourieu Nebout, N., Peyron, O., Dormoy, I., Desprat, S., Beaudouin, C., Kotthoff, U., and Marret, F.: Rapid climatic variability in the west Mediterranean during the last 25000 years from high resolution pollen data, Clim. Past, 5, 503-521, doi:10.5194/cp5-503-2009, 2009.

Combourieu Nebout, N., Dormoy, I., Sadori, L., Peyron, O., and Joannin, S.: Central Mediterranean vegetation and climate changes from Holocene pollen records in the Adriatic Sea area, Clim. Past, in preparation, 2012.

Conti, F., Abbate, G., Alessandrini, A., and Blasi, C.: An annotated checklist of the Italian vascular flora, Palombi Editori, Roma, 2005.

Cruise, G. M., Macphail, R. I., Linderholm, J., Maggi, R., and Marshall, P. D.: Lago di Bargone, Liguria, N Italy: a reconstruction of Holocene environmental and land-use history, Holocene, 19, 987-1003, 2009.

Davis, B. A. S. and Brewer, S.: Orbital forcing and role of the latitudinal insolation/temperature gradient, Clim. Dynam., 32, 143$165,2009$.

De Beaulieu, J., Miras, Y., Andrieu-Ponel, V., and Guiter, F.: Vegetation dynamics in north-western Mediterranean regions: Instability of the Mediterranean bioclimate, Plant Biosyst., 139, 114126, 2005

de Jong, E., Nestor, P. A., and Pennock, D. J.: The use of magnetic susceptibility to measure long-term soil redistribution, Catena, 32, 23-35, 1998.

Dearing, J. A., Hay, K. L., Baban, S. M. J., Huddleston, A. S., Wellington, E. M. H., and Loveland, P. J.: Magnetic susceptibility of soil: An evaluation of conflicting theories using a national data set, Geophys. J. Int., 127, 728-734, 1996.

Deline, P. and Orombelli, G.: Glacier fluctuations in the western Alps during the Neoglacial, as indicated by the Miage morainic amphitheater (Mont Blanc massif, Italy), Boreas, 34, 456-467, 2005.

Di Donato, V., Esposito, P., Russo-Ermolli, E., Scarano, A., and Cheddadi, R.: Coupled atmospheric and marine palaeoclimatic reconstruction for the last $35 \mathrm{ka}$ in the Sele Plain-Gulf of Salerno area (southern Italy), Quatern. Int., 190, 146-157, 2008.

Di Rita, F. and Magri, D.: Holocene drought, deforestation and evergreen vegetation development in the central Mediterranean: a 5500 year record from Lago Alimini Piccolo, Apulia, southeast Italy, Holocene, 19, 295-306, 2009.

Di Rita, F., Simone, O., Caldara, M., Gehrels, W. R., and Magri, D.: Holocene environmental changes in the coastal Tavoliere Plain (Apulia, southern Italy): A multiproxy approach, Palaeogeogr. Palaeocl., 310, 139-151, 2011.

Di Rita, F., Anzidei, A. P., and Magri, D.: A Lateglacial and early Holocene pollen record from Valle di Castiglione (Rome): vegetation dynamics and climate implications, Quatern. Int., doi:10.1016/j.quaint.2011.11.011, in press, 2012.

Dormoy, I., Peyron, O., Combourieu Nebout, N., Goring, S., Kotthoff, U., Magny, M., and Pross, J.: Terrestrial climate variability and seasonality changes in the Mediterranean region between 15000 and 4000 years BP deduced from marine pollen records,
Clim. Past, 5, 615-632, doi:10.5194/cp-5-615-2009, 2009.

Drescher-Schneider, R., de Beaulieu, J., Magny, M., WalterSimonnet, A., Bossuet, G., Millet, L., Brugiapaglia, E., and Drescher, A.: Vegetation history, climate and human impact over the last 15,000 years at Lago dell'Accesa (Tuscany, Central Italy), Veg. Hist. Archaeobot., 16, 279-299, 2007.

Drysdale, R., Zanchetta, G., Hellstrom, J., Maas, R., Fallick, A., Pickett, M., Cartwright, I., and Piccini, L.: Late Holocene drought responsible for the collapse of Old World civilizations is recorded in an Italian cave flowstone, Geology, 34, 101-104, 2006.

Favaretto, S., Asioli, A., Miola, A., and Piva, A.: Preboreal climatic oscillations recorded by pollen and foraminifera in the southern Adriatic Sea, Quatern. Int., 190, 89-102, 2008.

Finné, M., Holmgren, K., Sundqvist, H. S., Weiberg, E., and Lindblom, M.: Climate in the eastern Mediterranean, and adjacent regions, during the past 6000 years - A review, J. Archaeol. Sci., 38, 3153-3173, 2011.

Finsinger, W., Colombaroli, D., De Beaulieu, J. L., Valsecchi, V., Vanniere, B., Vescovi, E., Chapron, E., Lotter, A. F., Magny, M., and Tinner, W.: Early to mid-Holocene climate change at Lago dell'Accesa (central Italy): climate signal or anthropogenic bias?, J. Quaternary Sci., 25, 1239-1247, 2010.

Fleitmann, D., Burns, S. J., Mangini, A., Mudelsee, M., Kramers, J., Villa, I., Neff, U., Al-Subbary, A. A., Buettner, A., Hippler, D., and Matter, A.: Holocene ITCZ and Indian monsoon dynamics recorded in stalagmites from Oman and Yemen (Socotra), Quaternary Sci. Rev., 26, 170-188, 2007.

Fletcher, W. J., Sanchez Goñi, M. F., Peyron, O., and Dormoy, I.: Abrupt climate changes of the last deglaciation detected in a Western Mediterranean forest record, Clim. Past, 6, 245-264, doi:10.5194/cp-6-245-2010, 2010.

Frisia, S., Borsato, A., Mangini, A., Spötl, C., Madonia, G., and Sauro, U.: Holocene climate variability in Sicily from a discontinuous stalagmite record and the Mesolithic to Neolithic transition, Quaternary Res., 66, 388-400, 2006.

Gedye, S. J., Jones, R. T., Tinner, W., Ammann, B., and Oldfield, F.: The use of mineral magnetism in the reconstruction of fire history: a case study from Lago di Origlio, Swiss Alps, Palaeogeogr. Palaeocl., 164, 101-110, 2000.

Giraudi, C., Magny, M., Zanchetta, G., and Drysdale, R. N.: The Holocene climatic evolution of Mediterranean Italy: A review of the continental geological data, Holocene, 21, 105-115, 2011.

Guerricchio, A.: Fenomeni gravitativi profondi e struttura geologica nei monti di Fagnano Castello (Calabria settentrionale), Geol. Appl. Idrogeol., 20, 63-96, 1985.

Guilaine, J.: De la vague à la tombe, La conquête néolithique de la Méditerranée, Seuil, Paris, 2003.

Guiot, J.: Methodology of the last climatic cycle reconstruction in France from pollen data, Palaeogeogr. Palaeocl., 80, 49-69, 1990.

Heegaard, E., Birks, H. J. B., and Telford, R. J.: Relationships between calibrated ages and depth in stratigraphical sequences: an estimation procedure by mixed-effect regression, Holocene, 15, 612-618, 2005.

Ivy-Ochs, S., Kerschner, H., Maisch, M., Christl, M., Kubik, P. W., and Schlüchter, C.: Latest Pleistocene and Holocene glacier variations in the European Alps, Quaternary Sci. Rev., 28, 2137 2149, 2009. 
Jalut, G., Dedoubat, J. J., Fontugne, M., and Otto, T.: Holocene circum-Mediterranean vegetation changes: Climate forcing and human impact, Quatern. Int., 200, 4-18, 2009.

Joannin, S., Bassinot, F., Nebout, N. C., Peyron, O., and Beaudouin, $\mathrm{C}$.: Vegetation response to obliquity and precession forcing during the Mid-Pleistocene Transition in Western Mediterranean region (ODP site 976), Quaternary Sci. Rev., 30, 280-297, 2011.

Joannin, S., Vannière, B., Galop, D., Peyron, O., Haas, J.-N., Gilli, A., Chapron, E., Wirth, S. B., Anselmetti, F., Desmet, M., and Magny, M.: Climate and vegetation changes during the Lateglacial and Early-Mid Holocene at Lake Ledro (southern Alps, Italy), Clim. Past Discuss., 8, 5583-5632, doi:10.5194/cpd8-5583-2012, 2012.

Landi, M. and Angiolini, C.: Osmundo-Alnion woods in Tuscany (Italy): A phytogeographical analysis from a west European perspective, Plant Biosyst., 144, 93-110, 2010.

Leng, M. J., Baneschi, I., Zanchetta, G., Jex, C. N., Wagner, B., and Vogel, H.: Late Quaternary palaeoenvironmental reconstruction from Lakes Ohrid and Prespa (Macedonia/Albania border) using stable isotopes, Biogeosciences, 7, 3109-3122, doi:10.5194/bg7-3109-2010, 2010.

Lowe, J. J. and Watson, C.: Lateglacial and early Holocene pollen stratigraphy of the northern Apennines, Italy: A contribution to the "North Atlantic seaboard programme" of IGCP-253, "Termination of the Pleistocene", Quaternary Sci. Rev., 12, 727-738, 1993.

Magny, M.: Holocene climate variability as reflected by midEuropean lake-level fluctuations and its probable impact on prehistoric human settlements, Quatern. Int., 113, 65-79, 2004.

Magny, M. and Haas, J. N.: A major widespread climatic change around $5300 \mathrm{cal}$. yr BP at the time of the Alpine Iceman, J. Quaternary Sci., 19, 423-430, 2004.

Magny, M., Marguet, A., Chassepot, G., Richard, H., and Billaud, Y.: Early and late Holocene water-level fluctuations of Lake Annecy, France: sediment and pollen evidence and climatic implications, J. Paleolimnol., 25, 215-227, 2001.

Magny, M., Miramont, C., and Sivan, O.: Assessment of the impact of climate and anthropogenic factors on Holocene Mediterranean vegetation in Europe on the basis of palaeohydrological records, Palaeogeogr. Palaeocl., 186, 47-59, 2002.

Magny, M., De Beaulieu, J. L., Drescher-Schneider, R., Vannière, B., Walter-Simonnet, A. V., Millet, L., Bossuet, G., and Peyron, O.: Climatic oscillations in central Italy during the Last GlacialHolocene transition: the record from Lake Accesa, J. Quaternary Sci., 21, 311-320, 2006a.

Magny, M., Leuzinger, U., Bortenschlager, S., and Haas, J.: Tripartite climate reversal in Central Europe 5600-5300 years ago, Quaternary Res., 65, 3-19, 2006b.

Magny, M., de Beaulieu, J., Drescher-Schneider, R., Vannière, B., Walter-Simonnet, A., Miras, Y., Milleta, L., Bossueta, G., Peyron, O., Bruglapaglia, E., and Leroux, A.: Holocene climate changes in the central Mediterranean as recorded by lake-level fluctuations at Lake Accesa (Tuscany, Italy), Quaternary Sci. Rev., 26, 1736-1758, 2007a.

Magny, M., Vannière, B., de Beaulieu, J., Bégeot, C., Heiri, O., Millet, L., Peyron, O., and Walter-Simonnet, A.: Early-Holocene climatic oscillations recorded by lake-level fluctuations in westcentral Europe and in central Italy, Quaternary Sci. Rev., 26, 1951-1964, 2007b.
Magny, M., Vannière, B., Zanchetta, G., Fouache, E., Touchais, G., Petrika, L., Coussot, C., Walter-Simonnet, A. V., and Arnaud, F.: Possible complexity of the climatic event around $4300-3800 \mathrm{cal}$. BP in the central and western Mediterranean, Holocene, 19, 823-833, 2009.

Magny, M., Peyron, O., Sadori, L., Ortu, E., Zanchetta, G., Vannière, B., and Tinner, W.: Contrasting patterns of precipitation seasonality during the Holocene in the south- and northcentral Mediterranean, J. Quaternary Sci., 27, 290-296, 2011a.

Magny, M., Vannière, B., Calo, C., Millet, L., Leroux, A., Peyron, O., Zanchetta, G., Mantia, T. L., and Tinner, W.: Holocene hydrological changes in south-western Mediterranean as recorded by lake-level fluctuations at Lago Preola, a coastal lake in southern Sicily, Italy, Quaternary Sci. Rev., 30, 2459-2475, 2011 b.

Magny, M., Joannin, S., Galop, D., Vannière, B., Haas, J. N., Basseti, M., Bellintani, P., Scandolari, R., and Desmet, M.: Holocene palaeohydrological changes in the northern Mediterranean borderlands as reflected by the lake-level record of Lake Ledro, northeastern Italy, Quaternary Res., 77, 382-396, 2012.

Magri, D., Vendramin, G. G., Comps, B., Dupanloup, I., Geburek, T., Gomory, D., Latalowa, M., Litt, T., Paule, L., Roure, J. M., Tantau, I., van der Knaap, W. O., Petit, R. J., and De Beaulieu, J. L.: A new scenario for the Quaternary history of European beech populations: palaeobotanical evidence and genetic consequences, New Phytol., 171, 199-221, 2006.

Marchal, O., Cacho, I., Stocker, T. F., Grimalt, J. O., Calvo, E., Martrat, B., Shackleton, N., Vautravers, M., Cortijo, E., van Kreveld, S., Andersson, C., Koç, N., Chapman, M., Sbaffi, L., Duplessy, J. C., Sarnthein, M., Turon, J. L., Duprat, J., and Jansen, E.: Apparent long-term cooling of the sea surface in the northeast Atlantic and Mediterranean during the Holocene, Quaternary Sci. Rev., 21, 455-483, 2002.

Mayewski, P. A., Rohling, E. E., Stager, J. C., Karlén, W., Maasch, K. A., Meeker, L. D., Meyerson, E. A., Gasse, F., van Kreveld, S., Holmgren, K., Lee-Thorp, J., Rosqvist, G., Rack, F., Staubwasser, M., Schneider, R. R., and Steig, E. J.: Holocene climate variability, Quaternary Res., 62, 243-255, 2004.

Mazier, F.: Modélisation de la relation entre pluie pollinique actuelle, végétation et pratiques pastorales en moyenne montagne (Pyrénées et Jura), PhD thesis, Université de FrancheComté, Besançon, 243 pp., 2006.

Mercuri, A. M., Sadori, L., and Blasi, C.: Archaeobotany for cultural landscape and human impact reconstructions, Plant Biosyst., 144, 860-864, 2010.

Mercuri, A. M., Bandini Mazzanti, M., Torri, P., Vigliotti, L., Bosi, G., Florenzano, A., Olmi, L., and N'siala, I.: A marine/terrestrial integration for mid-late Holocene vegetation history and the development of the cultural landscape in the Po valley as a result of human impact and climate change, Veg. Hist. Archaeobot., 21, 353-372, 2012.

Miller, G. H., Brigham-Grette, J., Alley, R. B., Anderson, L., Bauch, H. A., Douglas, M. S. V., Edwards, M. E., Elias, S. A., Finney, B. P., Fitzpatrick, J. J., Funder, S. V., Herbert, T. D., Hinzman, L. D., Kaufman, D. S., MacDonald, G. M., Polyak, L., Robock, A., Serreze, M. C., Smol, J. P., Spielhagen, R., White, J. W. C., Wolfe, A. P., and Wolff, E. W.: Temperature and precipitation history of the Arctic, Quaternary Sci. Rev., 29, 1679-1715, 2010.

Moore, P. D., Webb, J. A., and Collinson, M. E.: Pollen Analysis, Blackwell Scientific Publications, London, 1991. 
Murgia, M., Puntillo, D., Cesca, G., and Sassi, N.: Aspetti vegetationale e palinologici del Lago Trifoglietti nella Catena Costiera (Calabria), Abstr. XXV Congr. S.I.B., 21-24 maggio, Rifreddo, Potenza, 5, 1984.

Naimo, D., Adamo, P., Imperato, M., and Stanzione, D.: Mineralogy and geochemistry of a marine sequence, Gulf of Salerno, Italy, Quatern. Int., 140-141, 53-63, 2005.

Noti, R., van Leeuwen, J. F. N., Colombaroli, D., Vescovi, E., Pasta, S., La Mantia, T., and Tinner, W.: Mid- and late-Holocene vegetation and fire history at Biviere di Gela, a coastal lake in southern Sicily, Italy, Veg. Hist. Archaeobot., 18, 371-387, 2009.

Ogniben, L.: Schema geologico della Calabria in base ai dati odierni, Geol. Romana, 12, 243-585, 1973.

Ogniben, L. and Vezzani, L.; Geologia e dissesti., in: Carta della montagna II: Monografie regionali, 18, Calabria, Ministero dell'Agricoltura e delle Foreste, Direzione Generale per l'Economia Montana e per le Foreste, Geotecneco, Pesaro, 53103, 1976.

Peyron, O., Goring, S., Dormoy, I., Kotthoff, U., Pross, J., de Beaulieu, J.L., Drescher-Schneider, R., Vannière, B., and Magny, M.: Holocene seasonality changes in central Mediterranean reconstructed from Lake Accesa and Tenaghi Philippon pollen sequences, Holocene, 21, 131-146, 2011.

Peyron, O., Magny, M., Goring, S., Joannin, S., de Beaulieu, J.L., Brugiapaglia, E., Sadori, L., Garfi, G., Kouli, K., Ioakim, C., and Combourieu-Nebout, N.: Contrasting patterns of climatic changes during the Holocene in the Central Mediterranean (Italy) reconstructed from pollen data, Clim. Past Discuss., 8, 58175866, doi:10.5194/cpd-8-5817-2012, 2012.

Piccarreta, M., Caldara, M., Capolongo, D., and Boenzi, F.: Holocene geomorphic activity related to climatic change and human impact in Basilicata, Southern Italy, Geomorphology, 128, 137-147, 2011.

Pignatti, S.: Introduzione allo studio fitosociologico della Pianura Veneta Orientale, Arch. Bot., 28-29, 65-98, 1953.

Pross, J., Kotthoff, U., Müller, U. C., Peyron, O., Dormoy, I., Schmiedl, G., Kalaitzidis, S., and Smith, A. M.: Massive perturbation in terrestrial ecosystems of the Eastern Mediterranean region associated with the $8.2 \mathrm{kyr} \mathrm{BP}$ climatic event, Geology, 37, 887-890, 2009.

Rasmussen, S., Vinther, B., Clausen, H., and Andersen, K.: Early Holocene climate oscillations recorded in three Greenland ice cores, Quaternary Sci. Rev., 26, 1907-1914, 2007.

Reille, M.: Pollen et Spores d'Europe et d'Afrique du nord, Laboratoire de Botanique Historique et Palynologie, Université d'AixMarseille, Marseille, 1992-1998.

Reimer, P. J., Baillie, M. G. L., Bard, E., Bayliss, A., Beck, J. W., Blackwell, P. G., Ramsey, C. B., Buck, C. E., Burr, G. S., Edwards, R. L., Friedrich, M., Grootes, P. M., Guilderson, T. P., Hajdas, I., Heaton, T. J., Hogg, A. G., Hughen, K. A., Kaiser, K. F., Kromer, B., McCormac, F. G., Manning, S. W., Reimer, R. W., Richards, D. A., Southon, J. R., Talamo, S., Turney, C. S. M., van der Plicht, J., and Weyhenmeye, C. E.: INTCAL09 and MARINE09 radiocarbon age calibration curves, 0-50,000 years cal BP, Radiocarbon, 51, 1111-1150, 2009.

Rivas-Martinez, S.: Bases para una nueva clasificacion bioclimatica de la tierra, Folia Botanica Madritensis, 10, 1-23, 1993.
Roberts, N., Brayshaw, D., Kuzucuoğlu, C., Perez, R., and Sadori, L.: The mid-Holocene climatic transition in the Mediterranean: Causes and consequences, Holocene, 21, 3-13, 2011a.

Roberts, N., Eastwood, W. J., Kuzucuoglu, C., Fiorentino, G., and Caracuta, V.: Climatic, végétation and cultural changes in the eastern Mediterranean during the mid-Holocene environmental transition, Holocene, 21, 147-162, $2011 \mathrm{~b}$.

Rohling, E. J., Mayewski, P. A., Abu-Zied, R. H., Casford, J. S. L., and Hayes, A.: Holocene atmosphere-ocean interactions: records from Greenland and the Aegean Sea, Clim. Dynam., 18, 587593, 2002.

Sadori, L. and Narcisi, B.: The Postglacial record of environmental history from Lago di Pergusa, Sicily, Holocene, 11, 655-671, 2001.

Sadori, L., Giraudi, C., Petitti, P., and Ramrath, A.: Human impact at Lago di Mezzano (central Italy) during the Bronze Age: a multidisciplinary approach, Quatern. Int., 113, 5-17, 2004.

Sadori, L., Zanchetta, G., and Giardini, M.: Last Glacial to Holocene palaeoenvironmental evolution at Lago di Pergusa (Sicily, Southern Italy) as inferred by pollen, microcharcoal, and stable isotopes, Quatern. Int., 181, 4-14, 2008.

Sadori, L., Mercuri, A. M., and Lippi, M. M.: Reconstructing past cultural landscape and human impact using pollen and plant macroremains, Plant Biosyst., 144, 940-951, 2010.

Sadori, L., Jahns, S., and Peyron, O.: Mid-Holocene vegetation history of the central Mediterranean, Holocene, 21, 117-129, 2011.

Sangiorgi, F., Capotondi, L., Combourieu Nebout, N., Vigliotti, L., Brinkhuis, H., Giunta, S., Lotter, A. F., Morigi, C., Negri, A., and Reichart, G.: Holocene seasonal sea-surface temperature variations in the southern Adriatic Sea inferred from a multiproxy approach, J. Quaternary Sci., 18, 723-732, 2003.

Sbaffi, L., Wezel, F. C., Kallel, N., Paterne, M., Cacho, I., Ziveri, P., and Shackleton, N.: Response of the pelagic environment to palaeoclimatic changes in the central Mediterranean Sea during the Late Quaternary, Mar. Geol., 178, 39-62, 2001.

Sbaffi, L., Wezel, F. C., Curzi, G., and Zoppi, U.: Millennialto centennial-scale palaeoclimatic variations during Termination I and the Holocene in the central Mediterranean Sea, Global Planet. Change, 40, 201-217, 2004.

Scarciglia, F., Robustelli, G., Tiné, V., La Russa, M. F., Abate, M., and Pezzino, A.: The role of human impacts and Holocene climate change in the Santuario della Madonna Cave (Calabria), Méditerranée, 112, 137-143, 2009.

Schneider, R.: Analyse palynologique dans l'Aspromonte en Calabre (Italie Meridionale), Cahiers ligures de Prehistoire et de Protohistoire, n.s., 2, 279-288, 1985.

Siani, G., Magny, M., Paterne, M., Debret, M., and Fontugne, M.: Paleohydrology reconstruction and Holocene climate variability in the South Adriatic Sea, Clim. Past Discuss., 8, 4357-4399, doi:10.5194/cpd-8-4357-2012, 2012.

Siani, G., Paterne, M., and Colin, C.: Late glacial to Holocene planktic foraminifera bioevents and climatic record in the South Adriatic Sea, J. Quaternary Sci., 25, 808-821, 2010.

Sperone, E., Bonacci, A., Brunelli, E., Corapi, B., and Tripepi, S.: Ecologia e conservazione dell'erpetofauna della Catena Costiera calabra, Studi Trent. Sci. Nat., Acta Biol., 83, 99-104, 2007.

Stuiver, M. and Reimer, P. J.: Extended ${ }^{14} \mathrm{C}$ database and revised CALIB radiocarbon calibration program, Radiocarbon, 35, 215230, 1993. 
ter Braak, C. J. F. and Juggins, S.: Weighted averaging partial least squares regression (WA-PLS): an improved method for reconstructing environmental variables from species assemblages, Hydrobiologia, 269/270, 485-502, 1993.

Testa, M., Gerbaudo, S., and Andri, E.: Data report: Botryococcus colonies in Miocene sediments in the western Woodlark Basin, southwest Pacific (ODP Leg 180), in: Proc. ODP, Sci. Results, edited by: Huchon, P., Taylor, B., and Klaus, A., 180, 1-6, 2001.

Thompson, R. and Oldfield, F.: Environmental Magnetism, Allen \& Unwin, London, 1986.

Tinner, W., van Leeuwen, J. F., Colombaroli, D., Vescovi, E., van der Knaap, W. O., Henne, P. D., Pasta, S., D'Angelo, S., and La Mantia, T.: Holocene environmental and climatic changes at Gorgo Basso, a coastal lake in southern Sicily, Italy, Quaternary Sci. Rev., 28, 1498-1510, 2009.

Tomaselli, M.: Conifer forests in the Apennines and Sicily, Ital. Habit., 18, 43-100, 2007.

van Geel, B., Heusser, C. J., Renssen, H., and Schuurmans, C. J. E.: Climatic change in Chile at around $2700 \mathrm{BP}$ and global evidence for solar forcing: a hypothesis, Holocene, 10, 659-664, 2000.

Vannière, B., Bossuet, G., Walter-Simonnet, A. V., Gauthier, E., Barral, P., Petit, C., Buatier, M., and Daubigney, A.: Land use change, soil erosion and alluvial dynamic in the lower Doubs Valley over the 1st millenium AD (Neublans, Jura, France), J. Archaeol. Res., 30, 1283-1299, 2003.

Vannière, B., Magny, M., Joannin, S., Simonneau, A., Wirth, S. B., Hamann, Y., Chapron, E., Gilli, A., Desmet, M., and Anselmetti, F. S.: Orbital changes, variation in solar activity and increased anthropogenic activities: controls on the Holocene flood frequency in the Lake Ledro area, Northern Italy, Clim. Past Discuss., 8, 4701-4744, doi:10.5194/cpd-8-4701-2012, 2012.
Watson, C. S.: The vegetational history of the northern Apennines, Italy: Information from three new sequences and a review of Regional vegetational change, J. Biogeogr., 23, 805-841, 1996.

Watts, W. A., Allen, J. R. M., Huntley, B., and Fritz, S. C.: Vegetation history and climate of the last 15,000 years at Laghi di Monticchio, southern Italy, Quaternary Sci. Rev., 15, 113-132, 1996.

Whitlock, C., Briles, C. E., Fernandez, M. C., and Gage, J.: Holocene vegetation, fire and climate history of the Sawtooth Range, central Idaho, USA, Quaternary Res., 75, 114-124, 2011.

Wiersma, A. P. and Jongma, J. I.: A role for icebergs in the $8.2 \mathrm{ka}$ climate event, Clim. Dynam., 35, 535-549, 2010.

Yu, S., Colman, S. M., Lowell, T. V., Milne, G. A., Fisher, T. G., Breckenridge, A., Boyd, M., and Teller, J. T.: Freshwater Outburst from Lake Superior as a Trigger for the Cold Event 9300 Years Ago, Science, 328, 1262-1266, 2010.

Zanchetta, G., Drysdale, R. N., Hellstrom, J. C., Fallick, A. E., Isola, I., Gagan, M. K., and Pareschi, M. T.: Enhanced rainfall in the western Mediterranean during deposition of sapropel 1: stalagmite evidence from Corchia cave (Central Italy), Quaternary Sci. Rev., 26, 279-286, 2007.

Zanchetta, G., Giraudi, C., Sulpizio, R., Magny, M., Drysdale, R. N., and Sadori, L.: Constraining the onset of the Holocene "Neoglacial" over the central Italy using tephra layers, Quaternary Res., 78, 236-247, 2012. 